\title{
Synthesis and Mesomorphic Properties of Rigid- Core Ionic Liquid Crystals
}

\author{
Paul H. J. Kouwer, Timothy M. Swager*
}

Contribution from the Department of Chemistry and Institute for Soldier Nanotechnologies, Massachusetts Institute of Technology, 77 Massachusetts Avenue, Cambridge, Massachusetts 02139, USA.

\section{Supporting Information:}

\section{Contents:}

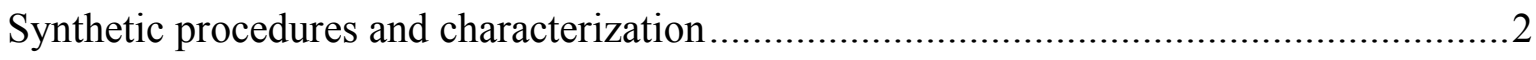

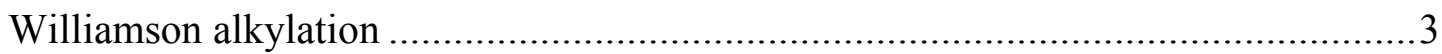

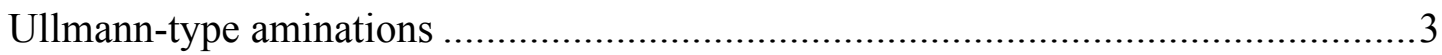

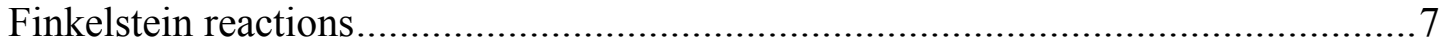

Alkylation reactions with different alkyl iodides............................................... 8

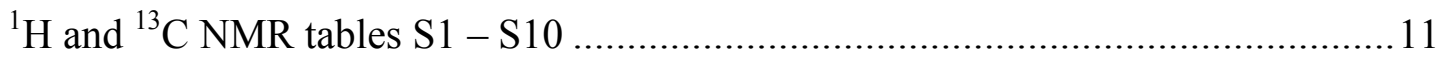

${ }^{1} \mathrm{H}$ and ${ }^{13} \mathrm{C}$ NMR chemical shift dependence on the counter ion...............................18

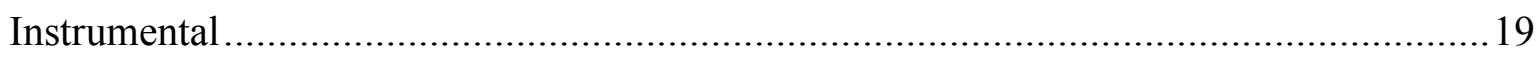

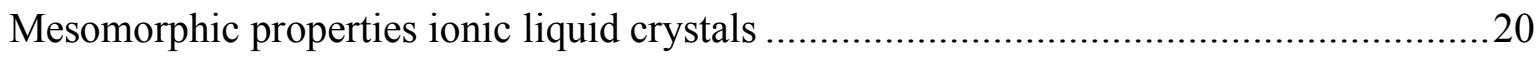

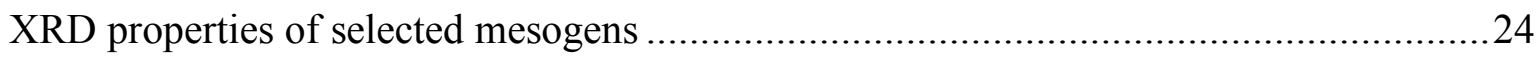

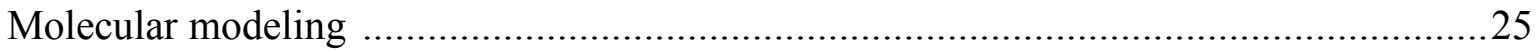

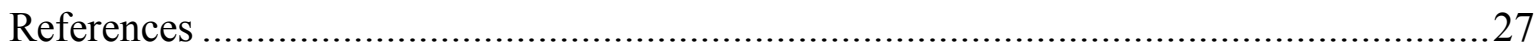




\section{Synthetic procedures and characterization}

Experimental. Synthesis and chemical characterization $\left({ }^{1} \mathrm{H},{ }^{13} \mathrm{C}\right.$ NMR $)$ of compounds 1-37 is described below. After purification by crystallization and/or column chromatography, the materials were dissolved in $\mathrm{CH}_{2} \mathrm{Cl}_{2}$, filtered $(0.2 \mu \mathrm{m}$ pores $)$ and the solvent was evaporated. Materials have been dried for $24 \mathrm{hrs}$ in vacuum before analysis. Mixtures of different ILCs have been prepared by dissolving the appropriate amounts of ILC in a common solvent, which then was removed by evaporation. Mixtures were dried for $24 \mathrm{hrs}$ under vacuum prior to analysis. Mixtures of ILCs with EDOT or $\mathrm{LiBF}_{4}$ were prepared by the addition of a stock solution of the salt (in THF) or the thiophene (in $\mathrm{CH}_{2} \mathrm{Cl}_{2}$ ) to a weighed amount of ILC. The solutions were filtered ( $0.2 \mu \mathrm{m}$ pores) and the solvent was evaporated. Mixtures were dried for $24 \mathrm{hrs}$ under vacuum prior to analysis.

Scheme 1. Synthesis of the ILC precursors. ${ }^{\text {a }}$
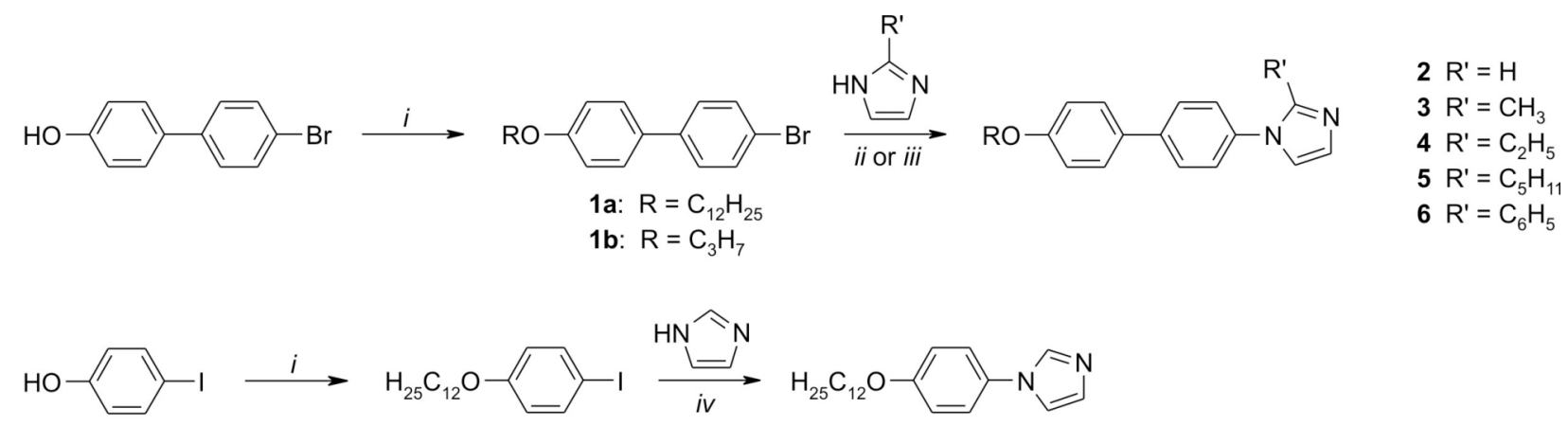

7

8

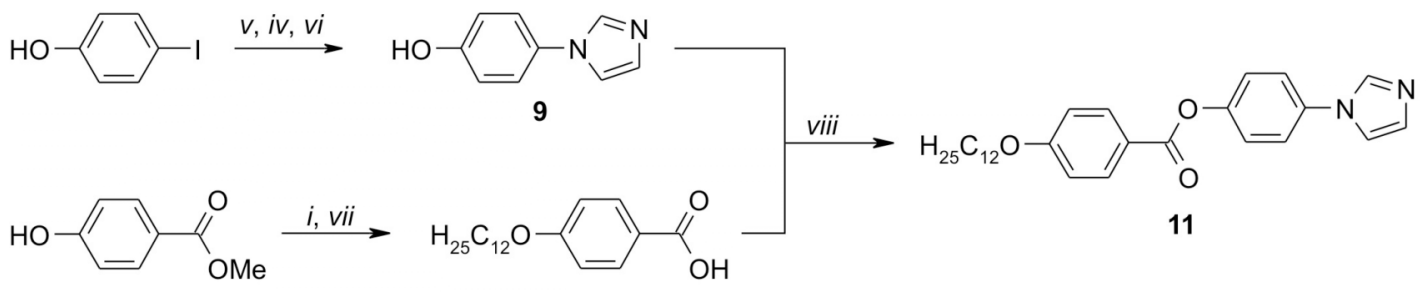

10

a Key: (i) $\mathrm{RBr}, \mathrm{K}_{2} \mathrm{CO}_{3}$, $\mathrm{KI}$, butanone, 16 hrs reflux; (ii) $\mathrm{K}_{2} \mathrm{CO}_{3}$, CuI, $N$, $N$-dimethylglycine, DMSO, 24-48 hrs at $110^{\circ} \mathrm{C}$; (iii) $\mathrm{Ce}_{2} \mathrm{CO}_{3}, \mathrm{CuI}, 4,7$-dimethoxy-1,10-phenanthroline, PEG-600, butyronitril 4-24 hrs reflux; (iv) $\mathrm{K}_{2} \mathrm{CO}_{3}$, CuI, L-proline, DMSO, 16 hrs at $110{ }^{\circ} \mathrm{C}$; (v) Tetrahydropyran, p-toluenesulphonic acid, $\mathrm{CH}_{2} \mathrm{Cl}_{2}, 2 \mathrm{hrs}$ at room temperature; (vi) $\mathrm{MeOH}, 1 \mathrm{~N} \mathrm{HCl}, 2$ hrs at room temperature; (vii) 1,3-Dicyclohexylcarbodiimide (DCC); 4 -( $N, N$-dimethylamino)pyridine (DMAP), THF, $40 \mathrm{hrs}$ at $50{ }^{\circ} \mathrm{C}$. 


\section{Williamson alkylation (1a, 1b, 7 and 10) - general procedure (scheme 1).}

The appropriate aromatic alcohol (1 eq.) and alkyl bromide (1.2 eq.), together with $\mathrm{K}_{2} \mathrm{CO}_{3}(2$ eq.), KI (0.2 eq.) were stirred in DMF at $150{ }^{\circ} \mathrm{C}$ until TLC indicated full conversion (3-6 hrs). The reaction mixture was cooled and filtered, the solids washed with acetone. The amount of DMF was reduced by partial evaporation (to $\sim 25 \%$ ) and the concentrated solution was precipitated in a $1 \mathrm{~N} \mathrm{HCl}$ solution. The product was extracted with $\mathrm{CH}_{2} \mathrm{Cl}_{2}(2 \mathrm{x})$ and the combined organic layers washed with $1 \mathrm{~N} \mathrm{HCl}(2 \mathrm{x})$ and water $(2 \mathrm{x})$. Pure product was obtained after recrystallization.

1a: recrystallization from ethanol, yield $91 \%$ of a white solid. Results of spectroscopic analysis are in correspondence with the literature. ${ }^{1}$

1b: recrystallization from ethanol, yield $84 \%$ of a white solid. Results of spectroscopic analysis are in correspondence with the literature. ${ }^{2}$

7: recrystallization from methanol, yield $89 \%$ of a white solid. Results of spectroscopic analysis are in correspondence with the literature. ${ }^{3}$

10: recrystallization from methanol, yield 77\% (first crop), 22\% (second crop) of a white solid. Deprotection of the ester: The first crop was refluxed with a $4 \mathrm{~N} \mathrm{KOH}$ solution (1.2 eq. $\mathrm{KOH}$ ) in EtOH. After $1 \mathrm{hr}$, the solution was cooled and acidified with a concentrated $\mathrm{HCl}$ solution until neutral. The precipitated product was filtered off and washed with aqueous methanol. After drying under vacuum 77\% (as calculated from the phenol starting material) of a white solid was obtained. Results of spectroscopic analysis are in correspondence with the literature. ${ }^{4}$

\section{Ullmann-type amination using $N, N$-dimethylglycine/CuI (2-4) - general procedure (see}

\section{scheme 1):}

The aryl bromide (1 eq.), imidazole derivative (1.2 eq.), $\mathrm{K}_{2} \mathrm{CO}_{3}$ (2 eq.), $\mathrm{CuI}$ (0.1 eq.) and $N, N$-dimethylglycine (0.2 eq.) were stirred in dry DMSO in inert atmosphere at $110{ }^{\circ} \mathrm{C}$. The mixture was cooled and precipitated into a large excess of $1 \mathrm{~N} \mathrm{NH}_{4} \mathrm{OH}$. The precipitate was filtered off, dissolved in $\mathrm{CH}_{2} \mathrm{Cl}_{2}$ and washed with $1 \mathrm{~N} \mathrm{NH}_{4} \mathrm{OH}(1 \mathrm{x})$ and water (2x), dried $\left(\mathrm{MgSO}_{4}\right)$ and the solvent was evaporated. Pure product was obtained by column chromatography $\left(\mathrm{SiO}_{2}\right)$, first eluting the aryl bromide starting material with $\mathrm{CH}_{2} \mathrm{Cl}_{2} /$ hexanes mixtures, then the product with EtOAc, followed by recrystallization from a $\mathrm{CH}_{2} \mathrm{Cl}_{2} /$ hexanes mixture.

2a: Reaction time: $48 \mathrm{~h}$; yield $79 \%$ of a white solid; $12 \%$ starting material was recovered. ${ }^{1} \mathrm{H}$ $\mathrm{NMR}\left(\mathrm{CDCl}_{3}, 500 \mathrm{MHz}\right): \delta=7.89\left(\mathrm{~s}, 1 \mathrm{H}\right.$, imidazole); 7.63, 7.52, 7.42, $6.99\left(4 \times \mathrm{d},{ }^{3} J_{\mathrm{HH}}=8.5\right.$ 
$\mathrm{Hz}, 4 \times 2 \mathrm{H}, \mathrm{CH}$ aromatic); 7.31, $7.23(2 \times \mathrm{br} \mathrm{s}, 2 \times 1 \mathrm{H}$, imidazole $) ; 4.00\left(\mathrm{t},{ }^{3} J_{\mathrm{HH}}=6.5 \mathrm{~Hz}, 2 \mathrm{H}\right.$, $\left.\mathrm{CH}_{2} \mathrm{O}\right) ; 1.81,1.50-1.22$ (m, 20H, $\mathrm{CH}_{2}$ aliphatic); 0.89 (t, 3H, $\left.\mathrm{CH}_{3}\right) .{ }^{13} \mathrm{C} \mathrm{NMR}\left(\mathrm{CDCl}_{3}, 125\right.$ MHz): $\delta=159.83,140.93,136.58,136.28,132.64,131.17,128.71,128.64,122.43,118.93$, 115.65, 68.84, 32.64, 30.39, 30.37, 30.33, 30.31, 30.13, 30.08, 29.98, 26.77, 23.42, 14.86 .

2b: Reaction time: $48 \mathrm{~h}$; yield $87 \%$ of a white solid; $5 \%$ starting material was recovered. ${ }^{1} \mathrm{H}$ $\operatorname{NMR}\left(\mathrm{CDCl}_{3}, 500 \mathrm{MHz}\right): \delta=7.91$ (br s, $1 \mathrm{H}$, imidazole); 7.66, 7.55, 7.45, $7.01\left(4 \times \mathrm{d},{ }^{3} J_{\mathrm{HH}}=\right.$ $8.5 \mathrm{~Hz}, 4 \times 2 \mathrm{H}, \mathrm{CH}$ aromatic); 7.33, $7.25\left(2 \times \mathrm{br} \mathrm{s}, 2 \times 1 \mathrm{H}\right.$, imidazole); $3.99\left(\mathrm{t},{ }^{3} J_{\mathrm{HH}}=6.5 \mathrm{~Hz}\right.$, $\left.2 \mathrm{H}, \mathrm{CH}_{2} \mathrm{O}\right) ; 1.86\left(\mathrm{~m}, 2 \mathrm{H}, \mathrm{CH}_{2}\right) 1.08\left(\mathrm{t},{ }^{3} J_{\mathrm{HH}}=6.5 \mathrm{~Hz}, 3 \mathrm{H}, \mathrm{CH}_{3}\right) .{ }^{13} \mathrm{C} \mathrm{NMR}_{\left(\mathrm{CDCl}_{3}, 125\right.}$ $\mathrm{MHz}): \delta=159.75,141.01,136.26,136.05,132.52$, 130.42, 128.64, 128.57, 122.36, 119.05, $115.61,70.29,23.21,11.14$.

3: Reaction time: $72 \mathrm{~h}$; yield: $56 \%$ of a white solid; $31 \%$ starting material was recovered. ${ }^{1} \mathrm{H}$ $\operatorname{NMR}\left(\mathrm{CDCl}_{3}, 500 \mathrm{MHz}\right): \delta=7.64,7.54,7.34,7.00\left(4 \times \mathrm{d},{ }^{3} J_{\mathrm{HH}}=8.5 \mathrm{~Hz}, 4 \times 2 \mathrm{H}, \mathrm{CH}\right.$ aromatic); 7.05, $7.04\left(2 \times \mathrm{d},{ }^{3} J_{\mathrm{HH}}=1.8 \mathrm{~Hz}, 2 \times 1 \mathrm{H}\right.$, imidazole $) ; 4.01\left(\mathrm{t},{ }^{3} J_{\mathrm{HH}}=6.5 \mathrm{~Hz}, 2 \mathrm{H}\right.$, $\mathrm{CH}_{2} \mathrm{O}$ ); 2.41 (s, 3H, $\mathrm{CH}_{3}$ imidazole); 1.84-178, 1.51-1.44, 1.40-1.22 (m, 20H, $\mathrm{CH}_{2}$ aliphatic); 0.89 (t, 3H, $\left.\mathrm{CH}_{3}\right) .{ }^{13} \mathrm{C} \mathrm{NMR}\left(\mathrm{CDCl}_{3}, 125 \mathrm{MHz}\right): \delta=159.87,145.46,141.53,137.20,132.70$, $128.82,128.46,128.24,126.45,121.38,115.65,68.84,32.64,30.38,30.36,30.33,30.30$, $30.12,30.07,29.98,26.77,23.41,14.85,14.60$.

4: Reaction time: $72 \mathrm{~h}$; yield: $27 \%$ of a white solid; $72 \%$ starting material was recovered. ${ }^{1} \mathrm{H}$ $\mathrm{NMR}\left(\mathrm{CDCl}_{3}, 500 \mathrm{MHz}\right): \delta=7.63,7.54,7.31,6.99\left(4 \times \mathrm{d},{ }^{3} J_{\mathrm{HH}}=8.5 \mathrm{~Hz}, 4 \times 2 \mathrm{H}, \mathrm{CH}\right.$ aromatic); 7.07, $7.00\left(2 \times \mathrm{d},{ }^{3} J_{\mathrm{HH}}=1.8 \mathrm{~Hz}, 2 \times 1 \mathrm{H}\right.$, imidazole $) ; 4.00\left(\mathrm{t},{ }^{3} J_{\mathrm{HH}}=6.5 \mathrm{~Hz}, 2 \mathrm{H}\right.$, $\left.\mathrm{CH}_{2} \mathrm{O}\right) ; 2.70\left(\mathrm{q},{ }^{3} J_{\mathrm{HH}}=7.5 \mathrm{~Hz}, 2 \mathrm{H}, \mathrm{CH}_{2} \mathrm{Im}\right) ; 1.84-178,1.50-1.44,1.39-1.22\left(\mathrm{~m}, 23 \mathrm{H}, \mathrm{CH}_{2}\right.$ aliphatic and $\left.\mathrm{CH}_{3}\right) ; 0.88\left(\mathrm{t}, 3 \mathrm{H}, \mathrm{CH}_{3}\right) .{ }^{13} \mathrm{C} \mathrm{NMR}\left(\mathrm{CDCl}_{3}, 125 \mathrm{MHz}\right): \delta=159.88,150.34$, $141.63,137.08,132.67,128.80,128.41,128.20,126.76,121.39,115.64,68.82,32.64,30.39$, $30.37,30.33,30.31,30.13,30.08,29.98,26.77,23.41,21.36,14.85,13.09$.

\section{Ullmann-type amination using $L$-proline/CuI (8 and 9) - general procedure (scheme 1).}

The aryl bromide ( 1 eq.), imidazole (1.5 eq.), $\mathrm{K}_{2} \mathrm{CO}_{3}$ (3 eq.), $\mathrm{CuI}$ (0.1 eq.) and $L$-proline (0.2 eq.) were stirred in dry DMSO in inert atmosphere at $130{ }^{\circ} \mathrm{C}$. The mixture was cooled and precipitated into a large excess of $1 \mathrm{~N} \mathrm{NH}_{4} \mathrm{OH}$. The precipitate was filtered off, dissolved in $\mathrm{CH}_{2} \mathrm{Cl}_{2}$ and washed with $1 \mathrm{~N} \mathrm{NH} 4 \mathrm{OH}(1 \mathrm{x})$ and water $(2 \mathrm{x})$, dried $\left(\mathrm{MgSO}_{4}\right)$ and the solvent was evaporated. Pure product was obtained by column chromatography $\left(\mathrm{SiO}_{2}\right.$, eluent EtOAc), followed by recrystallization from a $\mathrm{CH}_{2} \mathrm{Cl}_{2} /$ hexanes mixture. 
8: Reaction time: 6 h; yield: $92 \%$ of a white solid. ${ }^{1} \mathrm{H} \mathrm{NMR}\left(\mathrm{CDCl}_{3}, 500 \mathrm{MHz}\right): \delta=7.76$ (s, $1 \mathrm{H}$, imidazole); 7.28, $6.97\left(2 \times \mathrm{d},{ }^{3} J_{\mathrm{HH}}=8.5 \mathrm{~Hz}, 4 \times 2 \mathrm{H}, \mathrm{CH}\right.$ aromatic $) ; 7.20,7.18\left(2 \times \mathrm{t},{ }^{3} J_{\mathrm{HH}}=\right.$ $1.8 \mathrm{~Hz}, 2 \times 1 \mathrm{H}$, imidazole); $3.98\left(\mathrm{t},{ }^{3} J_{\mathrm{HH}}=6.5 \mathrm{~Hz}, 2 \mathrm{H}, \mathrm{CH}_{2} \mathrm{O}\right) ; 1.80\left(\mathrm{p},{ }^{3} J_{\mathrm{HH}}=6.5 \mathrm{~Hz}, 2 \mathrm{H}\right)$; 1.50-1.22 (m, 20H, $\mathrm{CH}_{2}$ aliphatic); $0.88\left(\mathrm{t}, 3 \mathrm{H}, \mathrm{CH}_{3}\right) .{ }^{13} \mathrm{C} \mathrm{NMR}\left(\mathrm{CDCl}_{3}, 125 \mathrm{MHz}\right): \delta=$ 159.21, 136.57, 131.19, 123.88, 119.48, 116.11, 69.14, 32.23, 30.37, 30.34, 30.31, 30.30, $30.09,30.06,29.89,26.71,23.40,14.84$.

9: Reaction time: $16 \mathrm{~h}$; yield: $80 \%$ of a white solid. ${ }^{1} \mathrm{H}$ NMR $\left(\mathrm{CDCl}_{3}, 500 \mathrm{MHz}\right): \delta=7.73(\mathrm{br}$ s, imidazole); 7.25, $7.11\left(2 \times \mathrm{d},{ }^{3} J_{\mathrm{HH}}=8.5 \mathrm{~Hz}, 2 \times 2 \mathrm{H}, \mathrm{CH}\right.$ aromatic $) ; 7.18,7.15(2 \times \mathrm{br} \mathrm{s}, 2 \times 1 \mathrm{H}$, imidazole); 5.41 (t, ${ }^{3} J_{\mathrm{HH}}=3.5 \mathrm{~Hz}, \mathrm{CH}$ THP), 3.89-3.83, 3.62-3.57, 2.05-1.93, 1.90-1.82, 1.76-1.55 (m, 8H, THP). $\left.{ }^{13} \mathrm{C} \mathrm{NMR} \mathrm{(} \mathrm{CDCl}_{3}, 125 \mathrm{MHz}\right): \delta=157.02,136.51,132.05,130.79$, $123.69,119.375,118.16,97.19,62.73,30.90,25.79,19.30$.

After deprotection of the THP group with $p$-toluenesulphonic acid in methanol (quantitative). ${ }^{1} \mathrm{H}$ NMR (DMSO- $\left.d_{6}, 500 \mathrm{MHz}\right): \delta=9.95$ (br s, $\left.1 \mathrm{H}, \mathrm{OH}\right) ; 8.04,7.56,7.04(3 \times \mathrm{s}, 3 \times 1 \mathrm{H}$, imidazole); 7.38, $6.85\left(2 \times \mathrm{d},{ }^{3} \mathrm{~J}_{\mathrm{HH}}=8.5 \mathrm{~Hz}, 2 \times 2 \mathrm{H}, \mathrm{CH}\right.$ aromatic $)$.

\section{Ullmann-type amination using 4,7-dimethoxy-1,10-phenanthroline/CuI (2a, 5 and 6) - general procedure (scheme 1).}

The aryl bromide (1 eq.), imidazole derivative (1.5 eq.), $\mathrm{Cs}_{2} \mathrm{CO}_{3}$ (3 eq.), $\mathrm{CuI}$ (0.025 eq.), 4,7dimethoxy-1,10-phenanthroline ( 0.075 eq.) and poly(ethyleneglycol) $\left(M_{\mathrm{w}}=600 \mathrm{~g} / \mathrm{mol}\right)$ were stirred in butyronitril in inert atmosphere at $130{ }^{\circ} \mathrm{C}$. The mixture was cooled and precipitated into a large excess of $5 \mathrm{~N} \mathrm{NH}_{4} \mathrm{OH}$. The precipitate was filtered off, dissolved in $\mathrm{CH}_{2} \mathrm{Cl}_{2}$ and washed with $1 \mathrm{~N} \mathrm{NH}_{4} \mathrm{OH}(1 \mathrm{x})$ and water $(2 \mathrm{x})$, dried $\left(\mathrm{MgSO}_{4}\right)$ and the solvent was evaporated. Pure product was obtained by column chromatography $\left(\mathrm{SiO}_{2}\right.$, eluent EtOAc), followed by recrystallization from a $\mathrm{CH}_{2} \mathrm{Cl}_{2} /$ hexanes mixture.

2a: Reaction time: 36 h; yield: $93 \%$ of a white solid. NMR analysis given above.

5: Reaction time: $40 \mathrm{~h}$; yield: $65 \%$ of a white solid. ${ }^{1} \mathrm{H}$ NMR $\left(\mathrm{CDCl}_{3}, 500 \mathrm{MHz}\right): \delta=7.59$, 7.54, 7.27, $6.99\left(4 \times \mathrm{d},{ }^{3} J_{\mathrm{HH}}=8.5 \mathrm{~Hz}, 4 \times 2 \mathrm{H}, \mathrm{CH}\right.$ aromatic); 7.48-7.44, 7.31-7.26 $(2 \times \mathrm{m}, 5 \mathrm{H}$, $\mathrm{Ph}) ; 7.30,7.21\left(2 \times \mathrm{d},{ }^{3} \mathrm{~J}_{\mathrm{HH}}=1.8 \mathrm{~Hz}, 2 \times 1 \mathrm{H}\right.$, imidazole $) ; 4.02\left(\mathrm{t},{ }^{3} \mathrm{~J}_{\mathrm{HH}}=6.5 \mathrm{~Hz}, 2 \mathrm{H}, \mathrm{CH}_{2} \mathrm{O}\right)$;

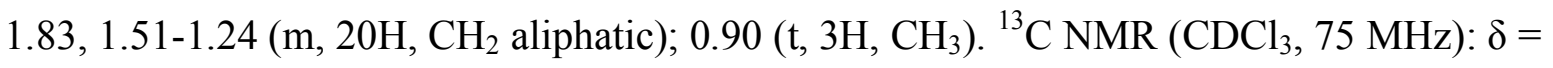
$159.93,149.54,141.65,137.20,132.74,128.83,128.47,128.20,126.88,121.32,115.70$, $68.89,32.66,32.25,30.38,30.34,30.15,30.09,30.02,28.58,27.87,26.80,23.43,23.07$, $14.86,14.66$. 
6: Reaction time: $40 \mathrm{~h}$; yield $62 \%$ of a white solid. ${ }^{1} \mathrm{H} \mathrm{NMR}\left(\mathrm{CDCl}_{3}, 500 \mathrm{MHz}\right): \delta=7.64$, 7.55, 7.32, $7.00\left(4 \times \mathrm{d},{ }^{3} J_{\mathrm{HH}}=8.5 \mathrm{~Hz}, 4 \times 2 \mathrm{H}, \mathrm{CH}\right.$ aromatic $) ; 7.07,7.01\left(2 \times \mathrm{d},{ }^{3} J_{\mathrm{HH}}=1.8 \mathrm{~Hz}\right.$, $2 \times 1 \mathrm{H}$, imidazole); $4.01\left(\mathrm{t},{ }^{3} \mathrm{~J}_{\mathrm{HH}}=6.5 \mathrm{~Hz}, 2 \mathrm{H}, \mathrm{CH}_{2} \mathrm{O}\right) ; 2.67\left(\mathrm{t},{ }^{3} J_{\mathrm{HH}}=6.5 \mathrm{~Hz}, 2 \mathrm{H}\right.$, $\left.\mathrm{CH}_{2} \mathrm{Im}\right) ; 1.85-1.78,1.74-1.68,1.51-1.22\left(\mathrm{~m}, 26 \mathrm{H}, \mathrm{CH}_{2}\right.$ aliphatic); 0.88, $0.84(2 \times \mathrm{t}, 2 \times 3 \mathrm{H}$, $\left.\mathrm{CH}_{3}\right) .{ }^{13} \mathrm{C} \mathrm{NMR}\left(\mathrm{CDCl}_{3}, 75 \mathrm{MHz}\right): \delta=159.94,147.50,141.44,137.81,132.64,131.17$, $129.87,129.39,129.07,128.96,128.80,128.20,126.83,123.66,115.72,68.92,32.68,30.40$, $30.36,30.16,30.11,30.03,26.81,23.45,14.88$.

11: Esterification of 9 and 10. A mixture of 10 (10 mmol), DMF (5 drops) and thionyl chloride $(10 \mathrm{~mL})$ was refluxed in toluene $(50 \mathrm{~mL})$. After $2 \mathrm{hrs}$, the solvent was removed under reduced pressure, dry toluene was added which was removed under reduced pressure again to remove traces of remaining thionyl chloride. This procedure was repeated one more time. The acid chloride was dissolved in pyridine $(25 \mathrm{~mL})$ and this solution was added dropwise over 5 minutes to a solution of $9(5 \mathrm{mmol})$ and 4 -( $N, N$-dimethylamino)pyridine (50 $\mathrm{mg})$ in pyridine $(30 \mathrm{~mL})$ cooled to $0{ }^{\circ} \mathrm{C}$. The reaction was allowed to warm to room temperature and terminated after 24 hrs by precipitation of the mixture in a $1 \mathrm{~N} \mathrm{HCl}$ solution. An aqueous work-up gave a crude product that was further purified by column chromatography $\left(\mathrm{SiO}_{2}\right.$, eluent EtOAc) and one recrystallization from methanol. Yield: 2.8 mmol (56\%) of a white solid. NMR: ${ }^{1} \mathrm{H}$ NMR $\left(\mathrm{CDCl}_{3}, 500 \mathrm{MHz}\right): \delta=8.15,7.43,7.32,6.99$ $\left(4 \times \mathrm{d},{ }^{3} J_{\mathrm{HH}}=8.5 \mathrm{~Hz}, 4 \times 2 \mathrm{H}, \mathrm{CH}\right.$ aromatic $) ; 7.84,7.27,7.22(3 \times \mathrm{s}, 3 \times 1 \mathrm{H}$, imidazole $) ; 4.04(\mathrm{t}$, $\left.{ }^{3} J_{\mathrm{HH}}=6.5 \mathrm{~Hz}, 2 \mathrm{H}, \mathrm{CH}_{2} \mathrm{O}\right) ; 2.70\left(\mathrm{q},{ }^{3} J_{\mathrm{HH}}=7.5 \mathrm{~Hz}, 2 \mathrm{H}, \mathrm{CH}_{2} \mathrm{Im}\right) ; 1.84-178,1.51-1.44,1.39-$ $1.22\left(\mathrm{~m}, 20 \mathrm{H}, \mathrm{CH}_{2}\right.$ aliphatic); $0.88\left(\mathrm{t},{ }^{3} \mathrm{~J}_{\mathrm{HH}}=6.5 \mathrm{~Hz}, 3 \mathrm{H}, \mathrm{CH}_{3}\right) .{ }^{13} \mathrm{C} \mathrm{NMR}\left(\mathrm{CDCl}_{3}, 125 \mathrm{MHz}\right)$ : $\delta=165.47,164.49,150.83,136.44,135.60,133.08,131.23,128.06,123.41,121.63,119.19$, $115.09,69.08,32.62,30.37,30.34,30.30,30.27,30.07,30.06,29.79,26.68,23.40,14.85$. 
Scheme 2. Synthesis of alkyl iodides. ${ }^{\mathrm{a}}$

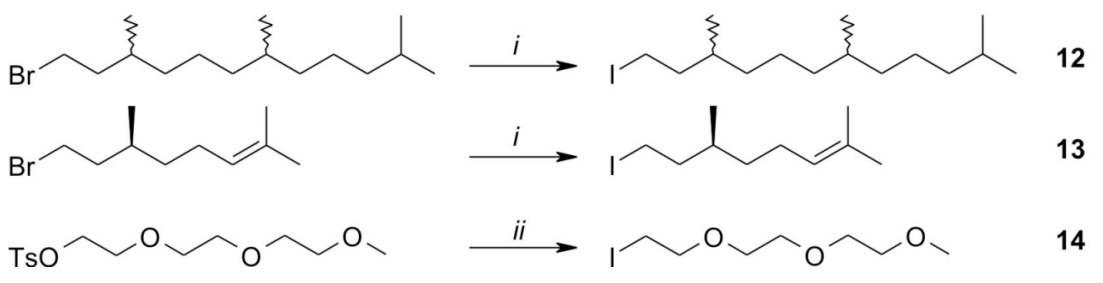

a Key: (i) NaI, acetone, 16 hrs at room temperature; (ii) KI, butanone, 16 hrs reflux

Finkelstein reactions: alkyl bromide to alkyl iodide (12 and 13) - general procedure (scheme 2):

A mixture of the alkylbromide $(40 \mathrm{mmol})$ and $\mathrm{NaI}(100 \mathrm{mmol})$ was stirred in acetone (50 $\mathrm{mL}$ ) in the dark at room temperature overnight. Then the solution was filtered and the solvent was removed under reduced pressure. The residue was dissolved in hexanes and the solution was washed with dilute $\mathrm{Na}_{2} \mathrm{~S}_{2} \mathrm{O}_{5}(1 \mathrm{x})$ and water $(3 \mathrm{x})$, dried $\left(\mathrm{MgSO}_{4}\right)$ and the solvent was evaporated. Additional purification was not required. Yields: $92 \%$ (for 12) and $94 \%$ (for 13) of a colorless liquid. Characterization is in correspondence with literature ${ }^{5,6}$

Finkelstein reactions: alkyl tosylate to alkyl iodide 14 (scheme 2):

A mixture of 3,6,9-trioxo-1-decyl tosylate $(20 \mathrm{mmol})$ and $\mathrm{NaI}(50 \mathrm{mmol})$ was refluxed in butanone $(50 \mathrm{~mL})$ in the dark overnight. After cooling to room temperature, the solution was filtered and the solvent was removed under reduced pressure. The residue was dissolved in hexanes and the solution was washed with dilute $\mathrm{Na}_{2} \mathrm{~S}_{2} \mathrm{O}_{5}(1 \mathrm{x})$ and water (3x), dried $\left(\mathrm{MgSO}_{4}\right)$ and the solvent was evaporated. Additional purification was not required. Yield: 76 $\%$ of a colorless liquid. Characterization is in accordance with literature. ${ }^{7}$ 
Scheme 3. Synthesis of the ILCs. ${ }^{\mathrm{a}}$

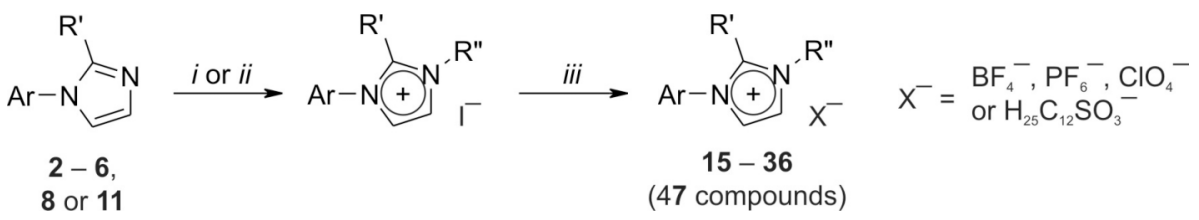

${ }^{a}$ Key: (i) Propyl or dodecyl iodide, neat, $4-24$ hrs at $100{ }^{\circ} \mathrm{C}$; (ii) 12, 13 or 14, toluene, $16-40$ hrs at $100{ }^{\circ} \mathrm{C}$; (iii) Ion exchange: $\mathrm{BF}_{4}{ }^{-}$and $\mathrm{PF}_{6}{ }^{-}$by multiple washes with concentrated aqueous $\mathrm{NaBF}_{4}$ or $\mathrm{NH}_{4} \mathrm{PF}_{6}$ solutions, respectively; $\mathrm{ClO}_{4}{ }^{-}$through a $\mathrm{AgClO}_{4}$ solution; $\mathrm{H}_{25} \mathrm{C}_{12} \mathrm{SO}_{3}{ }^{-}$(dodecyl sulphonate) through pre-functionalized beads.

\section{Alkylation reactions propyl iodide $(15,20,23,26,28,30,33)$ - general procedure:}

About $200 \mathrm{mg}$ of the imidazole derivative was heated in $n$-propyl iodide (ca. $3 \mathrm{~mL}$ ) at $80^{\circ} \mathrm{C}$ until TLC indicated complete conversion of the starting material (commonly 8-16 hrs). The mixture was cooled, hexanes were added and the precipitate was separated by centrifugation. The solids were dissolved in $\mathrm{CH}_{2} \mathrm{Cl}_{2}$, washed with dilute $\mathrm{Na}_{2} \mathrm{~S}_{2} \mathrm{O}_{5}$, water (2x) and concentrated $\mathrm{NaI}(1 \mathrm{x})$, dried $\left(\mathrm{MgSO}_{4}\right)$ and the solvent was evaporated. The crude product was dissolved in $\mathrm{CH}_{2} \mathrm{Cl}_{2}(<1 \mathrm{~mL})$ and precipitated with hexanes and centrifuged to separate off the product. This procedure was repeated 3x. After the final precipitation, the product was dissolved in $\mathrm{CH}_{2} \mathrm{Cl}_{2}$ and filtered over a $0.2 \mu \mathrm{m}$ filter and the solvent was evaporated. About $100 \mathrm{mg}$ of the product was used to prepare the tetrafluoroborate salt. The iodide was dissolved in $\mathrm{CH}_{2} \mathrm{Cl}_{2}(25 \mathrm{~mL})$ and the solution was washed with a concentrated aqueous $\mathrm{NaBF}_{4}$ solution $(25 \mathrm{~mL}, 3 \mathrm{x})$ and water $(2 \mathrm{x})$. The solution was dried $\left(\mathrm{MgSO}_{4}\right)$ and the solvent evaporated. The sample was crystallized at least four times (as described above) and filtered over a $0.2 \mu \mathrm{m}$ filter. NMR data of the iodides and the $\mathrm{BF}_{4}$ salts are shown in Tables $\mathrm{S} 1\left({ }^{1} \mathrm{H}\right.$ NMR) and S2 ( ${ }^{13} \mathrm{C}$ NMR). Yields are given in Tables 2 and 3 in the paper.

15c. A solution of $15 \mathbf{a}(115 \mathrm{mg}, 0.2 \mathrm{mmol})$ in $\mathrm{CH}_{2} \mathrm{Cl}_{2}(10 \mathrm{~mL})$ was washed with a concentrated aqueous $\mathrm{NH}_{4} \mathrm{PF}_{6}$ solution $(5 \mathrm{~mL}, 3 \mathrm{x})$ and water $(2 \mathrm{x})$. The solution was dried $\left(\mathrm{MgSO}_{4}\right)$ and the solvent evaporated. The sample was crystallized at least four times (as described above) and filtered over a $0.2 \mu \mathrm{m}$ filter. The NMR results are shown in Table S1 and S2. Yield: $98 \%$ of a white solid.

15d. A solution of $\mathbf{1 5 a}(115 \mathrm{mg}, 0.2 \mathrm{mmol})$ in THF $(20 \mathrm{~mL})$ was stirred with $\mathrm{AgClO}_{4}(0.3$ $\mathrm{mmol}$ ) in the dark at room temperature. After $16 \mathrm{hrs}$, the dark mixture was filtered through a plug of celite. The solvent was replaced with $\mathrm{CH}_{2} \mathrm{Cl}_{2}$ and the solution was washed with water (1x), dilute $\mathrm{Na}_{2} \mathrm{~S}_{2} \mathrm{O}_{5}$ and water $(2 \mathrm{x})$, dried $\left(\mathrm{MgSO}_{4}\right)$ and the solvent was evaporated. The 
sample was crystallized at least four times (as described above) and filtered over a $0.2 \mu \mathrm{m}$ filter. The NMR results are shown in Table S1 and S2. Yield: $88 \%$ of a white solid. Functionalized polystyrene beads (IRA-67, Aldrich) were prefunctionalised with dodecylsulphonate anions by stirring 1 gram of dry beads with a concentrated solution of sodium dodecylsulphonate in $50 \mathrm{~mL} \mathrm{THF} / \mathrm{methanol} \mathrm{(1:1).} \mathrm{After} 24 \mathrm{hrs}$, the beads were filtered from the solution and washed with water. This procedure was repeated once more.

15e. A mixture of 15a (115 mg, $0.2 \mathrm{mmol}$ ) and the pretreated beads (200 $\mathrm{mg}$ dry beads) in THF $(10 \mathrm{~mL})$ was stirred at room temperature. After $24 \mathrm{hrs}$, the beads were filtered off, washed with THF and fresh, pretreated beads $(200 \mathrm{mg})$ were added to the solution. After stirring for another $24 \mathrm{hrs}$, the beads were removed by filtration and the solvent was replaced by $\mathrm{CH}_{2} \mathrm{Cl}_{2}$. The solution was washed with water $(2 \mathrm{x})$, dried $\left(\mathrm{MgSO}_{4}\right)$ and the solvent was evaporated. The sample was crystallized at least four times (as described above) and filtered over a $0.2 \mu \mathrm{m}$ filter. The NMR results are shown in Table S1 and S2. Yield: $71 \%$ of a white solid.

33e. For the preparation of the dodecylsulphonate salt of 33a the procedure described above was followed. The NMR results are shown in Tables S1 and S2. Yield: $71 \%$ of a white solid.

\section{Alkylation reactions dodecyl iodide (16,21,24,27,29,31,32,34):}

The general procedure described for the propyl-substituted ILCs was used, but now the imidazole derivatives were stirred in 1-iodododecane (ca. $5 \mathrm{~mL}$ ) at $80{ }^{\circ} \mathrm{C}$. Reaction times generally increased somewhat (16-40 hrs) compared to the propyl iodide reactions. Work-up, as described above, consisted of an initial precipitation, aqueous washing of the product and multiple crystallizations from $\mathrm{CH}_{2} \mathrm{Cl}_{2}$ /hexane. After the final precipitation, the product was dissolved in $\mathrm{CH}_{2} \mathrm{Cl}_{2}$ and filtered over a $0.2 \mu \mathrm{m}$ filter and the solvent was evaporated. About $100 \mathrm{mg}$ of the product was used to prepare the tetrafluoroborate salt. The iodide was dissolved in $\mathrm{CH}_{2} \mathrm{Cl}_{2}(25 \mathrm{~mL})$ and the solution was washed with a concentrated aqueous $\mathrm{NaBF}_{4}$ solution $(25 \mathrm{~mL}, 3 \mathrm{x})$ and water $(2 \mathrm{x})$. The solution was dried $\left(\mathrm{MgSO}_{4}\right)$ and the solvent evaporated. The sample was crystallized at least four times (as described above) and filtered over a $0.2 \mu \mathrm{m}$ filter. NMR data of the iodides and the $\mathrm{BF}_{4}$ salts are shown in Tables $\mathrm{S} 3\left({ }^{1} \mathrm{H}\right.$ NMR) and S4 ( ${ }^{13} \mathrm{C}$ NMR). Yields are given in Tables 2 and 3 in the paper.

34e. For the preparation of the dodecylsulphonate salt from 34a the procedure described for 15e was followed. The NMR results are shown in Tables S3 and S4. Yield: $62 \%$ of a white solid. 


\section{Alkylation reactions 3,7,11-trimethyldodecyl iodide (17,22,25,35):}

A solution of the imidazole derivative $(200 \mathrm{mg})$ and 1-iodo-3,7,11-trimethyldodecane $(0.5$ $\mathrm{mL})$ in toluene $(3 \mathrm{~mL})$ was heated to $100{ }^{\circ} \mathrm{C}$ until TLC indicated complete conversion of the starting material (24-40 hrs). The mixture was cooled, hexanes were added and the precipitate was separated by centrifugation. The solids were dissolved in $\mathrm{CH}_{2} \mathrm{Cl}_{2}$, washed with dilute $\mathrm{Na}_{2} \mathrm{~S}_{2} \mathrm{O}_{5}$, water $(2 \mathrm{x})$ and concentrated $\mathrm{NaI}(1 \mathrm{x})$, dried $\left(\mathrm{MgSO}_{4}\right)$ and the solvent was evaporated. The crude product was dissolved in $\mathrm{CH}_{2} \mathrm{Cl}_{2}(<1 \mathrm{~mL})$ and precipitated with hexanes and centrifuged to separate off the product. This procedure was repeated 3x. After the final precipitation, the product was dissolved in $\mathrm{CH}_{2} \mathrm{Cl}_{2}$ and filtered over a $0.2 \mu \mathrm{m}$ filter and the solvent was evaporated.

About $100 \mathrm{mg}$ of the product was used to prepare the tetrafluoroborate salt. The iodide was dissolved in $\mathrm{CH}_{2} \mathrm{Cl}_{2}(25 \mathrm{~mL})$ and the solution was washed with a concentrated aqueous $\mathrm{NaBF}_{4}$ solution $(25 \mathrm{~mL}, 3 \mathrm{x})$ and water $(2 \mathrm{x})$. The solution was dried $\left(\mathrm{MgSO}_{4}\right)$ and the solvent evaporated. The sample was crystallized at least four times (as described above) and filtered over a $0.2 \mu \mathrm{m}$ filter. NMR data of the iodides and the $\mathrm{BF}_{4}$ salts are shown in Tables $\mathrm{S} 5\left({ }^{1} \mathrm{H}\right.$ $\mathrm{NMR})$ and $\mathrm{S} 6\left({ }^{13} \mathrm{C} \mathrm{NMR}\right)$. Yields are given in Tables 2 and 3 in the paper.

\section{Alkylation reactions citronellyl iodide (18):}

The procedure described for the trimethyldodecyl-substituted ILCs was followed (see above). The NMR results of the iodide and the $\mathrm{BF}_{4}$ salt are shown in Tables $\mathrm{S} 7\left({ }^{1} \mathrm{H}\right.$ NMR) and $\mathrm{S} 8$ $\left({ }^{13} \mathrm{C}\right.$ NMR). Yields are given in Tables 2 and 3 in the paper.

\section{Alkylation reactions 3,6,9-trioxadecyl iodide (19,36):}

The procedure described for the trimethyldodecyl-substituted ILCs was followed (see above). Reactions with this particular iodide, however, proceeded much faster (4-16 hrs, dependent on the concentration).

Work-up of the glycol was hampered a little due to the fact that they poorly crystallized from $\mathrm{CH}_{2} \mathrm{Cl}_{2}$ /hexanes mixtures (or impurities precipitated just as well). Therefore, both 19a and 36a were purified by column chromatography $\left(\mathrm{SiO}_{2}\right.$, eluent gradient $\mathrm{CH}_{2} \mathrm{Cl}_{2} / \mathrm{MeOH}(49: 1)$ to $\mathrm{CH}_{2} \mathrm{Cl}_{2} / \mathrm{MeOH}$ (9:1), after which the iodides crystallized better. In a second run (multi-gram scale reaction), 19a could be precipitated readily from the crude reaction mixture and chromatography was omitted. Iodides were converted to the $\mathrm{BF}_{4}$ salt according to the procedures described above. The NMR results of the iodide and the $\mathrm{BF}_{4}$ salt are shown in Tables S9 $\left({ }^{1} \mathrm{H}\right.$ NMR) and S10 $\left({ }^{13} \mathrm{C}\right.$ NMR). Yields are given in Tables 2 and 3 in the paper. 
Table S1: ${ }^{1} \mathrm{H}$ NMR data of propyl-substituted ILCs. The coupling constants and integrations are as shown for compound 15a, unless noted otherwise.

\begin{tabular}{|c|c|c|c|c|c|}
\hline ILC & O-tail (R) & aromatic $(\mathrm{Ar})$ & imidazole & 2-imidazole substituents (R') & Propyl (R”) \\
\hline 15a & $\begin{array}{l}3.96\left(\mathrm{t},{ }^{3} J_{\mathrm{HH}}=6.5 \mathrm{~Hz}, 2 \mathrm{H}\right) \\
1.78\left(\mathrm{p},{ }^{3} J_{\mathrm{HH}}=6.5 \mathrm{~Hz}, 2 \mathrm{H}\right) \\
1.48-1.21(\mathrm{~m}, 20 \mathrm{H}) \\
0.86\left(\mathrm{t},{ }^{3} J_{\mathrm{HH}}=6.5 \mathrm{~Hz}, 3 \mathrm{H}\right)\end{array}$ & $\begin{array}{l}7.82\left(\mathrm{~d},{ }^{3} J_{\mathrm{HH}}=8.5 \mathrm{~Hz}, 2 \mathrm{H}\right) \\
7.67\left(\mathrm{~d},{ }^{3} J_{\mathrm{HH}}=8.5 \mathrm{~Hz}, 2 \mathrm{H}\right) \\
7.46\left(\mathrm{~d},{ }^{3} J_{\mathrm{HH}}=8.5 \mathrm{~Hz}, 2 \mathrm{H}\right) \\
6.95\left(\mathrm{~d},{ }^{3} J_{\mathrm{HH}}=8.5 \mathrm{~Hz}, 2 \mathrm{H}\right)\end{array}$ & $\begin{array}{l}10.45(\mathrm{~s}, 1 \mathrm{H}) \\
7.80\left(\mathrm{dd},{ }^{3} J_{\mathrm{HH}}=1.8 \mathrm{~Hz}, 1 \mathrm{H}\right) \\
7.76\left(\mathrm{dd},{ }^{3} J_{\mathrm{HH}}=1.8 \mathrm{~Hz}, 1 \mathrm{H}\right)\end{array}$ & - & $\begin{array}{l}4.50\left(\mathrm{t},{ }^{3} J_{\mathrm{HH}}=7.0 \mathrm{~Hz}, 2 \mathrm{H}\right) \\
2.02(\mathrm{~m}, 2 \mathrm{H}) \\
1.01\left(\mathrm{t},{ }^{3} J_{\mathrm{HH}}=7.0 \mathrm{~Hz}, 3 \mathrm{H}\right)\end{array}$ \\
\hline 15b & $3.98,1.78,1.48-1.22,0.89$ & $7.65,7.62,7.45,6.95$ & $9.24,7.66,7.56$ & - & $4.31,1.95,0.98$ \\
\hline $15 \mathrm{~d}$ & $3.97,1.79,1.48-1.22,0.88$ & $7.63,7.60,7.44,6.94$ & $9.26,7.65,7.55$ & - & $4.31,1.95,0.97$ \\
\hline $15 \mathrm{e}^{a}$ & $3.98,1.80,1.48-1.22,0.88$ & $7.80,7.68,7.47,6.95$ & $10.53,7.71,7.50$ & - & $4.62,1.97,1.00$ \\
\hline 20a & $4.02,1.80,1.49-1.21,0.86$ & $8.07,7.92,7.36,6.95$ & $10.42,7.85,7.70$ & - & $4.48,2.02,1.00$ \\
\hline $20 \mathrm{~b}$ & $4.00,1.80,1.50-1.22,0.86$ & $8.05,7.66,7.32,6.94$ & $9.12,9.65,9.52$ & - & $4.25,1.93,0.94$ \\
\hline $26 \mathbf{b}$ & $3.99,1.81,1.50-1.22,0.88$ & $7.68,7.51,7.50,6.98$ & $7.48,7.28\left(2 \mathrm{xd},{ }^{3} J_{\mathrm{HH}}=1.8 \mathrm{~Hz}\right)$ & $2.59(\mathrm{~s}, 3 \mathrm{H})$ & $4.16,1.92,1.03$ \\
\hline 28a & $3.98,1.79,1.48-1.21,0.85$ & $7.70,7.65,7.51,6.98$ & $7.82,7.37\left(2 \mathrm{xd},{ }^{3} J_{\mathrm{HH}}=1.8 \mathrm{~Hz}\right)$ & $3.13\left(\mathrm{q},{ }^{3} J_{\mathrm{HH}}=7.0 \mathrm{~Hz}, 2 \mathrm{H}\right), 1.16\left(\mathrm{t},{ }^{3} J_{\mathrm{HH}}=7.0 \mathrm{~Hz}, 3 \mathrm{H}\right)$ & $4.32,2.04,1.08$ \\
\hline $28 \mathrm{~b}$ & $4.00,1.81,1.50-1.22,0.88$ & $7.70,7.51,7.50,6.99$ & $7.53,7.28\left(2 \mathrm{xd},{ }^{3} J_{\mathrm{HH}}=1.8 \mathrm{~Hz}\right)$ & $3.01\left(\mathrm{q},{ }^{3} J_{\mathrm{HH}}=7.0 \mathrm{~Hz}, 2 \mathrm{H}\right), 1.14\left(\mathrm{t},{ }^{3} J_{\mathrm{HH}}=7.0 \mathrm{~Hz}, 3 \mathrm{H}\right)$ & $4.18,1.98,1.06$ \\
\hline $30 a^{c}$ & $3.99,1.80,1.48-1.20,0.89$ & $7.71,7.69,7.52,7.00$ & $7.80,7.37$ & $\begin{array}{l}3.09\left(\mathrm{t},{ }^{3} J_{\mathrm{HH}}=7.0 \mathrm{~Hz}, 2 \mathrm{H}\right), 1.52-1.20(\mathrm{~m}, 6 \mathrm{H}, \\
\text { superposed with } \mathrm{C}_{12} \text {-tail), } 0.86\left(\mathrm{t},{ }^{3} J_{\mathrm{HH}}=7.0 \mathrm{~Hz}, 2 \mathrm{H}\right)\end{array}$ & $4.29,2.05,1.09$ \\
\hline $\mathbf{3 0 b}^{c}$ & $3.99,1.80,1.55-1.10,0.87$ & $7.67,7.51,7.27,6.98$ & $7.53,7.49$ & $\begin{array}{l}2.96,\left(\mathrm{t},{ }^{3} \mathrm{HH}_{\mathrm{HH}}=7.0 \mathrm{~Hz}, 2 \mathrm{H}\right), 1.55-1.10(\mathrm{~m}, 6 \mathrm{H}, \\
\text { superposed with } \mathrm{C}_{12} \text {-tail), } 0.76\left(\mathrm{t},{ }^{3} J_{\mathrm{HH}}=7.0 \mathrm{~Hz}, 2 \mathrm{H}\right)\end{array}$ & $4.15,1.97,1.05$ \\
\hline 33a & $3.91(\mathrm{t}), 1.78(\mathrm{~m}), 1.01(\mathrm{t})$ & $7.81,7.64,7.43,6.93$ & $10.54,7.83,7.79$ & - & $4.50,2.02,0.99$ \\
\hline
\end{tabular}

${ }^{a}$ Additional signals from the anion: $2.88(\mathrm{~m}, 2 \mathrm{H}), 1.87(\mathrm{~m}, 2 \mathrm{H}), 1.42-1.22\left(\mathrm{~m}, 18 \mathrm{H}\right.$ overlapping with the $18 \mathrm{H}$ of the $\mathrm{C}_{12}$ tail), $0.87\left(\mathrm{t},{ }^{3} J_{\mathrm{HH}}=7.0 \mathrm{~Hz}, 3 \mathrm{H}\right)$.

${ }^{b}$ Additional signals from the anion: $2.86(\mathrm{~m}, 2 \mathrm{H}), 1.86(\mathrm{~m}, 2 \mathrm{H}), 1.40-1.20(\mathrm{~m}, 18 \mathrm{H}), 0.85\left(\mathrm{t},{ }^{3} J_{\mathrm{HH}}=7.0 \mathrm{~Hz}, 3 \mathrm{H}\right)$.

${ }^{c}$ Collected on a $300 \mathrm{MHz}$ spectrometer.

Table S2: ${ }^{13}$ C NMR data of propyl-substituted ILCs.

\begin{tabular}{|c|c|c|c|c|c|}
\hline ILC & O-tail & aromatic & imidazole & Im-substituents & propyl \\
\hline $15 \mathrm{a}$ & $\begin{array}{l}68.87,32.61,30.37,30.33,30.31,30.29,30.12, \\
30.05,29.95,26.74,23.39,14.84\end{array}$ & $\begin{array}{l}160.23,143.55,133.31,131.56,129.01, \\
128.81,122.95,115.75\end{array}$ & $135.57,124.11,121.57$ & - & $52.64,24.51,11.47$ \\
\hline $15 \mathrm{c}$ & $\begin{array}{l}68.86,32.67,30.40,30.37,30.35,30.33,30.16 \text {, } \\
30.08,29.98,26.77,23.41,14.85\end{array}$ & $\begin{array}{l}160.27,143.68,133.36,131.47,128.96, \\
128.80,122.99,115.73\end{array}$ & $134.27,123.89,122.07$ & - & $52.64,24.09,11.25$ \\
\hline 15d & $\begin{array}{l}68.86,32.64,30.40,30.36,30.34,30.32,30.16, \\
30.08,29.98,26.77,23.41,14.85\end{array}$ & $\begin{array}{l}160.25,143.55,133.41,131.50,128.97, \\
128.80,122.94,115.73\end{array}$ & $134.93,124.01,121.98$ & - & $52.73,24.26,11.40$ \\
\hline $15 \mathrm{e}^{a}$ & $\begin{array}{l}68.85,32.64,30.39,30.37,30.36,30.33,30.31, \\
30.26,30.22,30.14,30.07,29.97,29.80,26.76, \\
26.23,23.40,14.84 \text { (some from anion) }\end{array}$ & $\begin{array}{l}\text { 160.20, 143.31, 133.55, 131.70, 129.00, } \\
128.78,122.60,115.71\end{array}$ & $137.28,123.38,121.09$ & - & $52.97,24.44,11.47$ \\
\hline
\end{tabular}


Supporting Information: Kouwer and Swager, lonic Liquid Crystals

\begin{tabular}{|c|c|c|c|c|c|}
\hline & $30.05,29.77,26.67,23.39,14.84$ & $124.74,124.19,121.11,115.17$ & & & \\
\hline $20 b$ & $\begin{array}{l}69.15,32.64,30.39,30.36,30.32,30.29,30.11, \\
30.08,29.83,26.71,23.41,14.85\end{array}$ & $\begin{array}{l}165.17,164.66,152.93,133.13,132.52, \\
124.71,124.06,122.19,115.19\end{array}$ & $135.08,122.17,121.23$ & - & $52.655,24.16,11.31$ \\
\hline $23 a$ & $\begin{array}{l}\text { 69.33, 32.59, 30.34, 30.31, 30.28, 30.25, 30.06, } \\
30.03,29.74,26.65,23.37,14.82\end{array}$ & $161.09,127.79,124.20,166.66$ & $135.45,123.97,121.86$ & - & $52.50,24.54,11.46$ \\
\hline $26 a$ & $\begin{array}{l}68.86,32.62,30.37,30.34,30.32,30.29,30.11, \\
30.06,29.94,26.75,23.57,14.85\end{array}$ & $\begin{array}{l}\text { 160.31, 144.34, 133.38, 131.76, 128.98, } \\
128.87,127.35,115.77\end{array}$ & $145.16,123.10,122.79$ & 13.31 & $51.97,23.40,11.46$ \\
\hline $26 b$ & $\begin{array}{l}68.87,32.63,30.39,30.36,30.33,30.31,30.14, \\
30.07,29.97,26.77,23.47,14.85\end{array}$ & $\begin{array}{l}160.28,144.16,133.55,131.79,128.96, \\
128.86,127.02,115.75\end{array}$ & $145.07,122.90,122.55$ & 11.62 & $51.17,23.41,11.08$ \\
\hline 28a & $\begin{array}{l}\text { 68.87, 32.61, 30.37, 30.33, 30.31, 30.28, 30.10, } \\
30.05,29.94,26.74,23.39,14.84\end{array}$ & $\begin{array}{l}\text { 160.33, 144.51, 133.32, 131.67, 128.99, } \\
128.93,127.36,115.77\end{array}$ & $149.19,123.62,122.88$ & $19.54,13.07$ & $51.60,24.13,11.89$ \\
\hline $28 b$ & $\begin{array}{l}\text { 68.87, 32.63, 30.38, 30.35, 30.33, 30.31, 30.13, } \\
30.07,29.96,26.76,23.41,14.85\end{array}$ & $\begin{array}{l}160.32,144.38,133.48,131.73,128.98, \\
128.92,127.18,115.76\end{array}$ & $149.03,123.47,122.54$ & $17.98,12.52$ & $50.92,23.99,11.66$ \\
\hline 30a ${ }^{c}$ & $\begin{array}{l}68.88,32.62,30.37,30.34,30.31,30.29,30.11, \\
30.06,29.93,26.74,23.40,14.85\end{array}$ & $\begin{array}{l}160.35,144.46,133.48,131.69,128.98, \\
128.86,127.44,115.79\end{array}$ & $148.56,123.57,122.72$ & $31.78,27.93,25.76,22.49,14.30$ & $51.63,23.98,11.09$ \\
\hline $\mathbf{3 0 b}^{c}$ & $\begin{array}{l}\text { 68.15, 31.87, 29.58, 29.55, 29.36, 29.30, 29.20, } \\
26.00,23.14,22.63,14.06\end{array}$ & $\begin{array}{l}\text { 159.61, 143.57, 132.89, 131.00, 128.22, } \\
128.11,126.45,115.06\end{array}$ & $147.51,122.77,121.81$ & $30.97,26.79,24.86,21.69,13.49$ & $50.21,23.38,10.92$ \\
\hline 33a & $70.32,23.23,11.22$ & $\begin{array}{l}160.19,143.45,133.32,131.57,128.97, \\
128.79,122.90,115.74\end{array}$ & $135.47,124.25,121.65$ & - & $52.54,24.53,11.46$ \\
\hline $33 \mathrm{e}^{b}$ & $70.30,23.26,11.22$ & $\begin{array}{l}160.16,143.15,133.56,131.68,128.91, \\
128.74,122.52,115.70\end{array}$ & $136.84,123.72,121.32$ & - & $52.43,24.43,11.43$ \\
\hline
\end{tabular}

${ }^{a}$ Additional signals from the anion: 52.56 and more in aliphatic area overlapping with the C12-tail of the mesogen.

${ }^{b}$ Additional signals from the anion: 53.00, 32.61, 30.38, 30.36, 30.35, 30.26, 30.22, 30.06, 29.80, 26.25, 23.39, 14.84.

${ }^{c}$ Collected on a $300 \mathrm{MHz}$ spectrometer. 
Table S3: ${ }^{1} \mathrm{H}$ NMR data of dodecyl-substituted ILCs. The coupling constants and integrations are as shown for compound 16a, unless noted otherwise.

\begin{tabular}{|c|c|c|c|c|c|}
\hline ILC & O-tail & aromatic & imidazole & Im-substituents & dodecyl \\
\hline $16 \mathbf{a}$ & $\begin{array}{l}3.98\left(\mathrm{t},{ }^{3} J_{\mathrm{HH}}=6.5 \mathrm{~Hz}, 2 \mathrm{H}\right) \\
1.80\left(\mathrm{p},{ }^{3} J_{\mathrm{HH}}=6.5 \mathrm{~Hz}, 2 \mathrm{H}\right) \\
1.49-1.42,1.40-1.20(\mathrm{~m}, 18 \mathrm{H}) \\
0.88 / 0.86\left(\mathrm{t},{ }^{3} J_{\mathrm{HH}}=6.5 \mathrm{~Hz}, 3 \mathrm{H}\right)\end{array}$ & $\begin{array}{l}7.84\left(\mathrm{~d},{ }^{3} J_{\mathrm{HH}}=8.5 \mathrm{~Hz}, 2 \mathrm{H}\right) \\
7.68\left(\mathrm{~d},{ }^{3} J_{\mathrm{HH}}=8.5 \mathrm{~Hz}, 2 \mathrm{H}\right) \\
7.47\left(\mathrm{~d},{ }^{3} J_{\mathrm{HH}}=8.5 \mathrm{~Hz}, 2 \mathrm{H}\right) \\
6.96\left(\mathrm{~d},{ }^{3} J_{\mathrm{HH}}=8.5 \mathrm{~Hz}, 2 \mathrm{H}\right)\end{array}$ & $\begin{array}{l}10.56(\mathrm{~s}, 1 \mathrm{H}) \\
7.79\left(\mathrm{dd},{ }^{3} J_{\mathrm{HH}}=1.8 \mathrm{~Hz}, 1 \mathrm{H}\right) \\
7.67\left(\mathrm{dd},{ }^{3} J_{\mathrm{HH}}=1.8 \mathrm{~Hz}, 1 \mathrm{H}\right)\end{array}$ & - & $\begin{array}{l}4.54\left(\mathrm{t},{ }^{3} J_{\mathrm{HH}}=6.5 \mathrm{~Hz}, 2 \mathrm{H}\right) \\
1.96\left(\mathrm{p},{ }^{3} J_{\mathrm{HH}}=6.5 \mathrm{~Hz}, 2 \mathrm{H}\right. \\
1.40-1.20(\mathrm{~m}, 18 \mathrm{H}) \\
0.88 / 0.86\left(\mathrm{t},{ }^{3} J_{\mathrm{HH}}=6.5 \mathrm{~Hz}, 3 \mathrm{H}\right)\end{array}$ \\
\hline $16 \mathrm{~b}$ & $4.00,1.80,1.49-1.20,0.86 / 0.85$ & $7.65,7.62,7.46,6.95$ & $9.28,7.64,7.60$ & - & $4.37,1.91,1.40-1.20,0.86 / 0.85$ \\
\hline 21a & $4.02,1.80,1.49-1.20,0.86 / 0.85$ & $8.07,7.93,7.35,6.94$ & $10.37,7.88,7.60$ & - & $4.48,1.96,1.40-1.20,0.86 / 0.85$ \\
\hline $21 b^{a}$ & $4.02,1.81,1.53-1.15,0.87 / 0.85$ & $8.06,7.66,7.32,7.94$ & $9.11,7.68,7.50$ & - & $4.28,1.89,1.40-1.15,0.87 / 0.85$ \\
\hline $24 a$ & $3.96,1.78,1.48-1.20,0.86 / 0.85$ & $7.69,7.02$ & $10.45,7,57,7.53$ & - & $4.53,1.97,1.40-1.20,0.87 / 0.86$ \\
\hline $24 \mathbf{b}^{a}$ & $3.94,1.77,1.50-1.18,0.86 / 0.85$ & $7.50,6.98$ & $9.08,7.58,7.52$ & - & $4.29,1.89,1.38-1.18,0.86 / 0.85$ \\
\hline $27 \mathbf{a}$ & $4.00,1.81,1.51-1.20,0.88 / 0.87$ & $7.71,7.70,7.51,6.99$ & $7.66,7.40$ & $2.80(\mathrm{~s}, 3 \mathrm{H})$ & $4.31,1.95,1.40-1.20,0.88 / 0.87$ \\
\hline $27 \mathbf{b}$ & $3.99,1.81,1.48-1.20,0.89 / 0.87$ & $7.67,7.51,7.50,6.98$ & $7.43,7.28$ & $2.58(\mathrm{~s}, 3 \mathrm{H})$ & $4.15,1.87,1.40-1.20,0.89 / 0.87$ \\
\hline 29a & $4.00,1.81,1.50-1.21,0.87$ & $7.72,7.70,7.52,6.99$ & $7.69,7.35$ & $\begin{array}{l}3.14\left(\mathrm{q}, 3 J_{\mathrm{HH}}=7.0 \mathrm{~Hz}, 2 \mathrm{H}\right) \\
1.18\left(\mathrm{t},{ }^{3} J_{\mathrm{HH}}=7.0 \mathrm{~Hz}, 3 \mathrm{H}\right)\end{array}$ & $4.33,1.98,1.41-1.21,0.87$ \\
\hline $29 b$ & $4.00,1.81,1.50-1.21,0.88$ & $7.70,7.52,7.51,6.98$ & $7.48,7.29$ & $\begin{array}{l}3.02\left(\mathrm{q},{ }^{3} J_{\mathrm{HH}}=7.0 \mathrm{~Hz}, 2 \mathrm{H}\right) \\
1.15\left(\mathrm{t},{ }^{3} J_{\mathrm{HH}}=7.0 \mathrm{~Hz}, 3 \mathrm{H}\right)\end{array}$ & $4.20,1.92,1.41-1.21,0.88$ \\
\hline $31 \mathrm{a}$ & $4.01,1.81,1.48-1.20,0.86$ & $7.71,7.70,7.54,7.00$ & $7.63,7.32$ & $3.10($ br t, $2 \mathrm{H}), 1.48-1.20(\mathrm{~m}, 6 \mathrm{H}), 0.86(\mathrm{~m}, 3 \mathrm{H})$ & $4.30,1.85,1.40-1.10,0.86$ \\
\hline $\mathbf{3 1 b}^{a}$ & $4.00,1.82,1.48-1.20,0.86-0.84$ & $7.70,7.69,7.50,6.96$ & $7.50,7.30$ & $2.95(\mathrm{t}, 2 \mathrm{H}) ; 1.48-1.20(\mathrm{~m}, 6 \mathrm{H}), 0.86-0.84(\mathrm{~m}, 3 \mathrm{H})$ & $4.17,1.89,1.48-1.20,0.86-0.84$ \\
\hline 32a & $3.94,1.76,1.46-1.10,0.85 / 0.84$ & $7.70,7.46,7.38,6.90$ & $8.04,7.69$ & $7.56-7.43(\mathrm{~m}, 5 \mathrm{H})$ & $4.21,1.85,1.46-1.10,0.85 / 0.84$ \\
\hline 32b & $3.93,1.78,1.48-1.10,0.86 / 0.85$ & $7.69,7.44,7.32,6.88$ & $7.92,7.63$ & $7.56-7.40(\mathrm{~m}, 5 \mathrm{H})$ & $4.21,1.87,1.48-1.10,0.86 / 0.85$ \\
\hline 33a & $3.94,1.82(\mathrm{~m}, 2 \mathrm{H}), 1.04(\mathrm{t}, 3 \mathrm{H})$ & $7.82,7.67,7.46,6.95$ & $10.55,7.77,7.64$ & - & $4.52,1.96,1.40-1.16,0.85$ \\
\hline 33b $^{a}$ & $3.94,1.82(\mathrm{~m}, 2 \mathrm{H}), 1.05(\mathrm{t}, 3 \mathrm{H})$ & $7.62,7.59,7.43,6.94$ & $9.18,7.65,7.50$ & - & $4.29,1.90,1.38-1.18,0.86$ \\
\hline 33e $\mathbf{e}^{a, b}$ & $3.97,1.84(\mathrm{~m}, 4 \mathrm{H}), 1.06(\mathrm{t}, 3 \mathrm{H})$ & $7.80,7.72,7.50,7.98$ & $10.57,7.59,7.37$ & - & $4.53,1.95,1.45-1.18,0.87$ \\
\hline
\end{tabular}

${ }^{a}$ Collected on a $300 \mathrm{MHz}$ spectrometer.

${ }^{b}$ Additional signals from the anion: $2.88(\mathrm{~m}, 2 \mathrm{H}), \sim 1.85(\mathrm{~m}, 2 \mathrm{H}), 1.45-1.18\left(\mathrm{~m}, 18 \mathrm{H}\right.$ overlapping with the $18 \mathrm{H}$ of the $\mathrm{C}_{12}$ tail), $0.87\left(\mathrm{t},{ }^{3} J_{\mathrm{HH}}=7.0 \mathrm{~Hz}, 3 \mathrm{H}\right)$. 
Table S4: ${ }^{13} \mathrm{C}$ NMR data of dodecyl-substituted ILCs.

\begin{tabular}{|c|c|c|c|c|c|}
\hline ILC & O-tail & aromatic & imidazole & Im-substituents & dodecyl substituent \\
\hline 16a & $\begin{array}{l}\text { 68.86, further aliphatic unresolved } \\
\text { - peak listing at dodecyl group }\end{array}$ & $\begin{array}{l}160.25,143.56,133.30 \\
131.53,129.00,128.81, \\
122.94,115.75\end{array}$ & $135.64,123.86,121.51$ & - & $\begin{array}{l}51.37,32.61,32.60,31.07,30.37,30.34,30.32 \\
30.30,30.23,30.13,30.11,30.06,30.04,29.95 \\
29.77,26.97,26.75,23.39,23.38,14.84\end{array}$ \\
\hline $16 \mathrm{~b}$ & $\begin{array}{l}\text { 68.86, further aliphatic unresolved } \\
\text { - peak listing at dodecyl group }\end{array}$ & $\begin{array}{l}160.27,143.71,133.39, \\
131.56,129.04,128.80, \\
122.87,115.76\end{array}$ & $135.21,123.61,121.71$ & - & $\begin{array}{l}51.27,32.63,32.62,30.75,30.37,30.35,30.32 \\
30.30,30.24,30.14,30.12,30.06,30.04,29.96 \\
29.83,26.98,26.76,23.40,14.85\end{array}$ \\
\hline $21 \mathrm{a}$ & $\begin{array}{l}69.12 \text {, further aliphatic unresolved } \\
\text { - peak listing at dodecyl group }\end{array}$ & $\begin{array}{l}165.21,164.66,152.83, \\
133.14,132.27,124.73, \\
124.15,121.11,115.16\end{array}$ & $135.67,123.92,121.87$ & - & $\begin{array}{l}\text { 51.39. 32.61, 32.60, 30.36, 30.33, 30.32, 30.30 } \\
30.29,30.26,30.23,30.11,30.07,30.05,30.04 \\
29.78,29.75,26.97,26.67,23.38,14.84\end{array}$ \\
\hline $21 b^{a}$ & $\begin{array}{l}69.15 \text {, further aliphatic unresolved } \\
\text { - peak listing at dodecyl group }\end{array}$ & $\begin{array}{l}165.18,164.67,152.88 \\
133.13,132.52,124.68, \\
123.99,122.17,115.18 \\
\end{array}$ & $134.97,123.97,121.22$ & - & $\begin{array}{l}51.29,32.64,30.81,30.35,30.12,30.08,29.83 \\
29.74,26.99,26.72,23.41,14.84\end{array}$ \\
\hline $24 a$ & $\begin{array}{l}\text { 69.36, further aliphatic unresolved } \\
\text { - peak listing at dodecyl group }\end{array}$ & $\begin{array}{l}161.19,127.76,124.24 \\
11.72\end{array}$ & $135.87,123.35,121.55$ & - & $\begin{array}{l}51.35,32.62,32.60,31.07,30.37,30.34,30.31 \\
30.30,30.28,30.22,30.10,30.08,30.06,30.04 \\
29.77,29.76,26.97,26.66,23.39 .14 .84\end{array}$ \\
\hline $24 b^{a}$ & $\begin{array}{l}69.34 \text {, further aliphatic unresolved } \\
\text { - peak listing at dodecyl group }\end{array}$ & $\begin{array}{l}161.16,127.96,124.12, \\
116.67\end{array}$ & $134.76,123.78,122.28$ & - & $\begin{array}{l}51.18,32.63,30.93,30.34,30.13,30.07,29.82 \\
29.74,26.97,26.71,23.40,14.83\end{array}$ \\
\hline $27 a$ & $\begin{array}{l}\text { 68.86, further aliphatic unresolved } \\
\text { - peak listing at dodecyl group }\end{array}$ & $\begin{array}{l}160.31,144.31,133.40, \\
131.75,128.97,128.85, \\
127.37,115.76\end{array}$ & $145.13,123.15,122.62$ & 13.36 & $\begin{array}{l}50.61,32.62,32.60,30.37,30.34,30.32,30.29 \\
30.24,30.15,30.11,30.08,30.06,30.04,29.94 \\
29.83,27.29,26.75,23.40,14.84\end{array}$ \\
\hline $27 \mathrm{~b}$ & $\begin{array}{l}\text { 69.85, further aliphatic unresolved } \\
\text { - peak listing at dodecyl group }\end{array}$ & $\begin{array}{l}160.27,144.09,133.57, \\
131.77,128.94,128.81, \\
127.01,115.74\end{array}$ & $144.96,122.95,122.43$ & 11.08 & $\begin{array}{l}49.74,32.63,32.62,30.39,30.36,30.33,30.32 \\
30.27,30.17,30.14,30.07,30.06,29.97,29.82 \\
27.21,26.77,23.41,23.40,14.85\end{array}$ \\
\hline $29 a$ & $\begin{array}{l}68.88 \text {, further aliphatic unresolved } \\
\text { - peak listing at dodecyl group }\end{array}$ & $\begin{array}{l}160.36,149.58,133.37 \\
131.69,129.00,128.93 \\
127.43,115.79\end{array}$ & $149.33,123.56,122.56$ & $19.71,13.00$ & $\begin{array}{l}\text { 50.36, 32.62, 32.61, 30.59, 30.38, 30.35, 30.32, } \\
30.29,30.23,30.14,30.11,30.06,30.04,29.94 \text {, } \\
29.84,27.33,26.75,23.40,14.85\end{array}$ \\
\hline $29 b$ & $\begin{array}{l}\text { 68.87, further aliphatic unresolved } \\
\text { - peak listing at dodecyl group }\end{array}$ & $\begin{array}{l}160.27,149.04,133.47, \\
131.72,128.98,128.83, \\
127.21,115.77\end{array}$ & $149.04,123.48,122.37$ & $18.03,12.52$ & $\begin{array}{l}49.57,32.63,32.62,30.67,30.38,30.36,30.33 \\
30.31,30.25,30.15,30.13,30.07,30.06,29.96 \\
29.83,27.28,26.76,23.40,14.85\end{array}$ \\
\hline $31 \mathbf{a}^{a}$ & $\begin{array}{l}68.90 \text {, further aliphatic unresolved } \\
- \text { peak listing at dodecyl group }\end{array}$ & $\begin{array}{l}160.36,144.45,133.52, \\
131.71,128.96,128.83 \\
127.45,115.81\end{array}$ & $148.55,123.64,122.61$ & $31.80,27.30,23.38,22.49,14.27$ & $\begin{array}{l}50.30,32.60,30.50,30.30,30.23,30.12,30.10 \\
30.03,29.94,29.82,27.89,26.74,25.84,14.81\end{array}$ \\
\hline 31b ${ }^{a}$ & $\begin{array}{l}68.86 \text {, further aliphatic unresolved } \\
\text { - peak listing at dodecyl group }\end{array}$ & $\begin{array}{l}160.30,144.21,133.63, \\
131.71,128.92,128.79, \\
127.17,115.76\end{array}$ & $148.11,123.57,122.46$ & $31.72,27.23,23.37,22.43,14.24$ & $\begin{array}{l}49.51,32.60,30.55,30.31,30.24,30.13,30.11 \\
30.03,29.95,29.79,27.50,26.74,24.12,14.80\end{array}$ \\
\hline $32 \mathbf{a}^{a}$ & $\begin{array}{l}68.84 \text {, further aliphatic unresolved } \\
\text { - peak listing at dodecyl group }\end{array}$ & $\begin{array}{l}160.20,145.06,133.74, \\
131.67,128.82,128.35, \\
127.16,115.68\end{array}$ & $143.50,123.77,121.91$ & $133.09,132.00,130.24,124.41$ & $\begin{array}{l}50.93,32.58,30.40,30.27,30.23,30.12,30.07 \\
30.01,29.90,29.82,27.90,26.70,14.79\end{array}$ \\
\hline
\end{tabular}




\begin{tabular}{|c|c|c|c|c|c|}
\hline 32b & $\begin{array}{l}68.65 \text {, further aliphatic unresolved } \\
\text { - peak listing at dodecyl group }\end{array}$ & $\begin{array}{l}160.01,144.88,133.64, \\
131.66,128.84,128.74, \\
127.02,115.64\end{array}$ & $143.15,123.62,121.78$ & $133.02,131.88,130.21,124.44$ & $\begin{array}{l}50.43,32.59,30.43,30.30,30.24,30.14,30.08 \\
30.02,29.90,29.82,27.62,26.72,14.80\end{array}$ \\
\hline $33 \mathbf{a}$ & $70.33,23.25,11.23$ & $\begin{array}{l}160.25,143.59,133.30 \\
131.57,129.05,128.83 \\
122.94,115.76\end{array}$ & $135.73,123.72,121.41$ & - & $\begin{array}{l}51.40,32.60,31.06,30.31,30.30,30.22,30.11 \\
30.03,29.77,26.97,23.38,14.84\end{array}$ \\
\hline 33b $\mathbf{b}^{a}$ & $70.38,23.32,11.25$ & $\begin{array}{l}160.29,143.56,133.47 \\
131.59,128.98,128.83 \\
122.84,115.80\end{array}$ & $134.88,123.89,121.92$ & - & $\begin{array}{l}51.31,32.65,30.90,30.36,30.28,30.15,30.08 \\
29.75,27.00,23.42,14.85\end{array}$ \\
\hline $33 \mathbf{e}^{a, b}$ & $70.42,23.34,11.88$ & $\begin{array}{l}160.28,143.61,133.44, \\
131.87,129.18,129.91, \\
122.85,115.82\end{array}$ & $137.79,122.97,120.91$ & - & $\begin{array}{l}51.45,32.68,32.01,31.15,30.44,30.38,30.34 \\
30.30,30.17,30.13,29.96,29.86,27.10,26.25 \\
23.45,14.88\end{array}$ \\
\hline
\end{tabular}

${ }^{a}$ Collected on a $75 \mathrm{MHz}$ spectrometer.

${ }^{b}$ Additional signals from the anion: 52.98 and more in aliphatic area overlapping with the C12-tail of the mesogen.

Table S5: ${ }^{1} \mathrm{H}$ NMR data of 3,7,11-trimethyldodecyl-substituted ILCs. The coupling constants and integrations are as shown for compound 17a, unless noted otherwise.

\begin{tabular}{|l|l|l|l|l|}
\hline ILC & O-tail & aromatic & Imidazole & trimethyldodecyl substituent \\
\hline $\mathbf{1 7 a}$ & $3.95\left(\mathrm{t},{ }^{3} J_{\mathrm{HH}}=6.5 \mathrm{~Hz}, 2 \mathrm{H}\right)$ & $7.84\left(\mathrm{~d},{ }^{3} J_{\mathrm{HH}}=8.5 \mathrm{~Hz}, 2 \mathrm{H}\right)$ & $10.54(\mathrm{~s}, 1 \mathrm{H})$ & $4.59-4.46(\mathrm{~m}, 2 \mathrm{H})$ \\
& $1.82\left(\mathrm{p},{ }^{3} J_{\mathrm{HH}}=6.5 \mathrm{~Hz}, 2 \mathrm{H}\right)$ & $7.64\left(\mathrm{~d},{ }^{3} J_{\mathrm{HH}}=8.5 \mathrm{~Hz}, 2 \mathrm{H}\right)$ & $7.88\left(\mathrm{dd},{ }^{3} J_{\mathrm{HH}}=1.8 \mathrm{~Hz}, 1 \mathrm{H}\right)$ & $2.03-1.94,1.83-1.76(\mathrm{~m}, 2 \mathrm{H})$ \\
& $1.50-1.20(\mathrm{~m}, 20 \mathrm{H})$ & $7.43\left(\mathrm{~d},{ }^{3} J_{\mathrm{HH}}=8.5 \mathrm{~Hz}, 2 \mathrm{H}\right)$ & $7.69\left(\mathrm{dd},{ }^{3} J_{\mathrm{HH}}=1.8 \mathrm{~Hz}, 1 \mathrm{H}\right)$ & $\begin{array}{l}1.60-0.96(\mathrm{~m}, 14 \mathrm{H}) \\
0.97\left(\mathrm{~d},{ }^{3} J_{\mathrm{HH}}=6.0 \mathrm{~Hz}, 3 \mathrm{H}\right) \\
0.83-0.79\left(3 \times \mathrm{xd},{ }^{3} J_{\mathrm{HH}}=6.5 \mathrm{~Hz}, 9 \mathrm{H}\right)\end{array}$ \\
& $0.86\left(\mathrm{t},{ }^{3} J_{\mathrm{HH}}=6.5 \mathrm{~Hz}, 3 \mathrm{H}\right)$ & $6.93\left(\mathrm{~d},{ }^{3} J_{\mathrm{HH}}=8.5 \mathrm{~Hz}, 2 \mathrm{H}\right)$ & & $4.38-4.22,2.00-0.78(\mathrm{~m})$ \\
\hline $\mathbf{1 7} \mathbf{b}^{a}$ & $3.96,1.90-0.78(\mathrm{~m})$ & & & $4.53-4.46,2.03-1.94,1.83-1.76,1.60-0.96,0.98,0.83-0.79$. \\
\hline $\mathbf{2 2 a}$ & $4.03,1.81,1.50-1.20,0.85$ & $8.01,7.60,7.43,6.93$ & $9.18,7.66,7.49$ & $4.39-4.26,1.98-1.88,1.77-1.68,1.60-0.99,0.96,0.90-0.80$. \\
\hline $\mathbf{2 2 b}$ & $4.03,1.82,1.50-1,20,0.85$ & $8.09,7.68,7.35,6.96$ & $10.38,7.89,7.52$ & $4.61-4.48,2.02-1.94,1.84-1.76,1.58-0.98,0.99,0.89-0.80$ \\
\hline $\mathbf{2 5 a}$ & $3.96,1.77,1.50-1,20,0.85$ & $7.69,7.01$ & $9.13,7.64,7.44$ & $4.42-4.20,2.00-0.78(\mathrm{~m})$ \\
\hline $\mathbf{2 5 b} \mathbf{b}^{a}$ & $3.94,1.90-0.78(\mathrm{~m})$ & $7.50,6.97$ & $10.42,7.58,7.50$ & $4.58-4.47,2.02-1.94,1.81-1.73,1.56-0.95,0.98,0.83-0.78$ \\
\hline $\mathbf{3 5 a}$ & $3.92,1.80(\mathrm{~m}, 2 \mathrm{H}), 1.03(\mathrm{t}, 3 \mathrm{H})$ & $7.83,7.64,7.43,6.93$ & $10.55,7.84,7.65$ & $4.40-4.18,2.02-0.78(\mathrm{~m})$ \\
\hline $\mathbf{3 5 b} \mathbf{b}^{a}$ & $3.93,1.82(\mathrm{~m}, 2 \mathrm{H}), 1.04(\mathrm{t}, 3 \mathrm{H})$ & $7.60,7.59,7.41,6.92$ & $9.19,7.70,7.52$ & \\
\hline
\end{tabular}

${ }^{a}$ Collected on a $300 \mathrm{MHz}$ spectrometer. 
Table S6: ${ }^{13} \mathrm{C}$ NMR data of 3,7,11-trimethyldodecyl -substituted ILCs.

\begin{tabular}{|c|c|c|c|c|}
\hline ILC & O-tail & aromatic & Imidazole & trimethyldodecyl substituent $^{a}$ \\
\hline $17 \mathbf{a}$ & $\begin{array}{l}68.87,32.60,30.35,30.32 \\
30.30,30.28,30.11,30.04 \\
29.94,26.74,23.37,14.83\end{array}$ & $\begin{array}{l}160.21,143.41,133.31,131.53,128.92 \\
128.77,122.90,115.71\end{array}$ & $135.49,123.93,121.81$ & $\begin{array}{l}49.67,40.00,38.22,38.05,37.95,37.93,37.91,37.80,37.79,33.46,33.44, \\
31.18,28.63,25.49,25.46,24.99,24.97,23.42,23.31,20.39,20.30,20.02, \\
19.96\end{array}$ \\
\hline $17 \mathbf{b}^{b}$ & $\begin{array}{l}68.92,32.68,30.20,30.11 \\
30.04,26.82,23.37,14.87\end{array}$ & $\begin{array}{l}160.30,143.51,133.48,131.56,128.95, \\
128.82,122.84,115.79\end{array}$ & $134.84,123.83,121.99$ & $\begin{array}{l}\text { 49.66, 40.09, 38.13, 38.07, 38.01, 37.81, 33.53, 31.25, 30.39, 28.71, 25.55, } \\
25.02,25.00,23.46,20.40,20.32,19.69,19.63\end{array}$ \\
\hline $22 \mathrm{a}$ & $\begin{array}{l}69.12,32.63,30.37,30.35 \\
30.31,30.27,30.08,30.06 \\
29.79,26.69,23.40,14.85\end{array}$ & $\begin{array}{l}165.29,164.69,152.89,133.17,132.23 \\
124.80,124.16,121.10,115.18\end{array}$ & $135.84,123.58,121.70$ & $\begin{array}{l}49.81,40.04,38.16,38.08,38.07,37.98,37.96,37.94,37.93,37.79,37.77 \text {, } \\
33.49,33.48,31.19,28.67,25.52,25.50,25.02,25.00,23.45,23.34,20.41, \\
20.32,20.02,19.95\end{array}$ \\
\hline $22 \mathbf{b}$ & $\begin{array}{l}69.12,32.62,30.38,30.35 \\
30.31,30.28,30.09,30.06 \\
29.80,26.69,23.40,14.85\end{array}$ & $\begin{array}{l}165.23,164.66,152.93,133.14,123.41 \\
124.77,123.99,121.14,115.16\end{array}$ & $135.09,123.73,122.01$ & $\begin{array}{l}49.67,40.04,38.79,38.15,38.06,37.98,37.96,37.75,37.74,33.49,33.48, \\
31.19,28.67,25.52,25.50,25.00,24.97,23.44,23.34,20.37,20.29,19.69 \text {, } \\
19.62\end{array}$ \\
\hline 25a & $\begin{array}{l}69.35,32.62,30.37,30.34 \\
30.31,30.27,30.08,30.06 \\
29.76,26.67,23.44,14.84\end{array}$ & $161.17,127.77,124.26,116.71$ & $135.90,123.24,121.65$ & $\begin{array}{l}49.73,40.03,38.22,38.14,38.06,37.95,37.94,37.80,37.79,33.48,33.47, \\
31.18,28.67,25.51,25.49,24.99,24.98,23.46,23.33,20.41,20.32,20.05 \text {, } \\
19.99\end{array}$ \\
\hline $25 \mathbf{b}^{b}$ & $\begin{array}{l}69.32,30.35,30.12,30.07 \\
29.82,26.71,23.41,14.83\end{array}$ & $161.15,127.98,124.13,116.66$ & $134.76,123.70,122.36$ & $\begin{array}{l}\text { 49.53, 40.06, 38.11, 37.99, 37.79, 33.50, 32.64, 31.21, 28.68, 25.51, 24.99, } \\
24.97,23.43,23.34,20.38,20.30,19.67,19.61\end{array}$ \\
\hline 35 & $70.31,23.24,11.22$ & $\begin{array}{l}160.21,143.47,133.31,131.56,128.97 \\
128.80,122.92,115.74\end{array}$ & $135.56,123.83,121.73$ & $\begin{array}{l}49.71,40.01,38.22,38.12,38.05,37.96,37.94,37.80,37.79,33.46,33.45 \text {, } \\
31.19,28.64,25.50,25.47,25.00,24.97,23.43,23.32,20.40,20.31,20.03 \text {, } \\
19.97\end{array}$ \\
\hline $35 \mathbf{b}^{b}$ & $70.32,23.28,11.22$ & $\begin{array}{l}160.22,143.39,133.46,131.55,128.88, \\
128.76,122.74,115.74\end{array}$ & $134.65,123.91,122.04$ & $\begin{array}{l}49.59,40.04,38.08,38.05,37.97,37.77,33.48,31.22,28.66,25.50,24.99, \\
24.96,23.43,23.32,20.36,20.28,19.63,19.57\end{array}$ \\
\hline
\end{tabular}

${ }^{a}$ Note that due to a the mixture of stereo isomers, a large number of signals from aliphatic carbon atoms is observed.

${ }^{b}$ Collected on a $75 \mathrm{MHz}$ spectrometer.

Table S7: ${ }^{1} \mathrm{H}$ NMR data of $(S)$-citronellyl-substituted ILCs. The coupling constants and integrations are as shown for compound $\mathbf{1 7 a}$, unless noted otherwise.

\begin{tabular}{|l|l|l|l|l|}
\hline ILC & O-tail & aromatic & imidazole & citronellyl substituent \\
\hline $\mathbf{1 8 a}$ & $3.97\left(\mathrm{t},{ }^{3} J_{\mathrm{HH}}=6.5 \mathrm{~Hz}, 2 \mathrm{H}\right)$ & $7.83\left(\mathrm{~d},{ }^{3} J_{\mathrm{HH}}=8.5 \mathrm{~Hz}, 2 \mathrm{H}\right)$ & $10.56(\mathrm{~s}, 1 \mathrm{H})$ & $5.03\left(\mathrm{t},{ }^{3} J_{\mathrm{HH}}=7.0 \mathrm{~Hz}, 1 \mathrm{H}, \mathrm{C}=\mathrm{CH}\right)$ \\
& $1.82-1.74,1.40-1.20(\mathrm{~m}, 22 \mathrm{H}-$ incl. 2 & $7.66\left(\mathrm{~d},{ }^{3} J_{\mathrm{HH}}=8.5 \mathrm{~Hz}, 2 \mathrm{H}\right)$ & $7.85\left(\mathrm{dd},{ }^{3} J_{\mathrm{HH}}=1.8 \mathrm{~Hz}, 1 \mathrm{H}\right)$ & $4.60-4.47(\mathrm{~m}, 2 \mathrm{H})$, \\
& protons from the citronellyl group) & $7.45\left(\mathrm{~d},{ }^{3} J_{\mathrm{HH}}=8.5 \mathrm{~Hz}, 2 \mathrm{H}\right)$ & $7.67\left(\mathrm{dd},{ }^{3} J_{\mathrm{HH}}=1.8 \mathrm{~Hz}, 1 \mathrm{H}\right)$ & $2.04-1.76(\mathrm{~m}, 4 \mathrm{H})$ \\
& $0.86\left(\mathrm{t},{ }^{3} J_{\mathrm{HH}}=6.5 \mathrm{~Hz}, 3 \mathrm{H}\right)$ & $6.95\left(\mathrm{~d},{ }^{3} J_{\mathrm{HH}}=8.5 \mathrm{~Hz}, 2 \mathrm{H}\right)$ & & $1.63(\mathrm{~s}, 3 \mathrm{H}), 1.56(\mathrm{~s}, 3 \mathrm{H})$, \\
& & & & $1.00\left(\mathrm{~d},{ }^{3} J_{\mathrm{HH}}=7.0 \mathrm{~Hz}, 3 \mathrm{H}\right)$ \\
\hline $\mathbf{1 8 b}{ }^{a}$ & $3.96,1.82-1.74,1.40-1.20,0.86$ & $7.61,7.60,7.42,7.92$ & $9.18,7.67,7.51$ & $5.02,4.40-4.20,2.05-1.75,1.62,1.55,0.94$ \\
\hline
\end{tabular}

${ }^{a}$ Collected on a $300 \mathrm{MHz}$ spectrometer. 
Table S8: ${ }^{13} \mathrm{C}$ NMR data of $(S)$-citronellyl-substituted ILCs.

\begin{tabular}{|l|l|l|l|l|}
\hline ILC & O-tail & aromatic & imidazole & citronellyl substituent \\
\hline $\mathbf{1 8 a}$ & $68.85,32.60,30.36,30.33,30.31$, & $160.22,143.48,133.32,131.55$, & $135.58,123.89,121.71$ & $132.39,124.79,49.64,38.05,37.37,30.65,26.42,25.95,19.93,18.48$ \\
& $30.29,30.12,30.05,29.95,26.75$, & $128.97,128.80,122.93,115.73$ & & \\
& $23.39,14.84$ & & \\
\hline $\mathbf{1 8 b}^{a}$ & $68.91,32.67,30.38,30.20,30.11$, & $160.29,143.50,133.50,131.58$, & $134.79,123.92,122.02$ & $132.40,124.87,49.59,37.87,37.36,30.72,26.42,25.96,19.61,18.42$ \\
& $30.03,26.82,23.44,14.87$ & $128.95,128.82,122.83,115.78$ & & \\
\hline
\end{tabular}

${ }^{a}$ Collected on a $75 \mathrm{MHz}$ spectrometer.

Table S9: ${ }^{1} \mathrm{H}$ NMR data of 3,6,9-trioxadecyl-substituted ILCs. The coupling constants and integrations are as shown for compound 19a, unless noted otherwise.

\begin{tabular}{|l|l|l|l|l|}
\hline ILC & O-tail & aromatic & imidazole & glycol substituent \\
\hline $\mathbf{1 9 a}$ & $3.99\left(\mathrm{t},{ }^{3} J_{\mathrm{HH}}=6.5 \mathrm{~Hz}, 2 \mathrm{H}\right)$ & $7.79\left(\mathrm{~d},{ }^{3} J_{\mathrm{HH}}=8.5 \mathrm{~Hz}, 2 \mathrm{H}\right)$ & $10.30(\mathrm{~s}, 1 \mathrm{H})$ & $4.81\left(\mathrm{t},{ }^{3} J_{\mathrm{HH}}=7.0 \mathrm{~Hz}, 2 \mathrm{H}\right)$ \\
& $1.82-1.74,1.40-1.20(\mathrm{~m}, 20 \mathrm{H})$ & $7.70\left(\mathrm{~d},{ }^{3} J_{\mathrm{HH}}=8.5 \mathrm{~Hz}, 2 \mathrm{H}\right)$ & $8.03\left(\mathrm{dd},{ }^{3} J_{\mathrm{HH}}=1.8 \mathrm{~Hz}, 1 \mathrm{H}\right)$ & $4.02-4.00,3.72-3.70,3.64-3.60,3.50-3.48(4 \times \mathrm{xm}, 10 \mathrm{H})$ \\
& $0.87\left(\mathrm{t},{ }^{3} J_{\mathrm{HH}}=6.5 \mathrm{~Hz}, 3 \mathrm{H}\right)$ & $7.48\left(\mathrm{~d},{ }^{3} J_{\mathrm{HH}}=8.5 \mathrm{~Hz}, 2 \mathrm{H}\right)$ & $7.68\left(\mathrm{dd},{ }^{3} J_{\mathrm{HH}}=1.8 \mathrm{~Hz}, 1 \mathrm{H}\right)$ & $3.30(\mathrm{~s}, 3 \mathrm{H})$ \\
& & $\left.6.96(\mathrm{~d}){ }^{3} J_{\mathrm{HH}}=8.5 \mathrm{~Hz}, 2 \mathrm{H}\right)$ & & \\
\hline $\mathbf{1 9 b}$ & $4.02,1.86-1.80,1.52-1.24,0.90$ & $7.74,7.65,7.53,7.01$ & $9.36,7.86,7.52$ & $4.61,3.97-3.95,3.72-3.70,3.67-3.63,3.53-3.51,3.33$ \\
\hline $\mathbf{3 6 a}$ & $3.97,1.86-1.79(\mathrm{~m}, 2 \mathrm{H}), 1.05(\mathrm{t}, 3 \mathrm{H})$ & $7.77,7.71,7.47,6.97$ & $10.40,7.97,7.61$ & $4.81,4.01-3.98,3.72-3.69,3.65-3.59,3.51-3.48,3.30$ \\
\hline $\mathbf{3 6 b}{ }^{a}$ & $3.95,1.90-1.78(\mathrm{~m}, 2 \mathrm{H}), 1.05(\mathrm{t}, 3 \mathrm{H})$ & $7.68,7.61,4.47,6.96$ & $9.24,7.79,7.57$ & $4.53,3.93-3.89,3.69-3.57,3.51-3.45,3.28$ \\
\hline
\end{tabular}

Table S10: ${ }^{13} \mathrm{C}$ NMR data of 3,6,9-trimethyldodecyl -substituted ILCs.

\begin{tabular}{|l|l|l|l|l|}
\hline ILC & O-tail & aromatic & imidazole \\
\hline $\mathbf{1 9 a}$ & $68.85,32.60,30.35,30.33,30.30,30.28,30.10$, & $160.23,143.57,133.47,131.61,129.00$, & $135.81,125.48,121.01$ & $72.35,70.92,70.87,70.77,69.49,59.70,50.91$ \\
& $30.04,29.93,26.73,23.38,14.83$ & $128.83,123.15,115.74$ & \\
\hline $\mathbf{1 9 b}$ & $68.88,32.65,30.40,30.37,30.35,30.33,30.16$, & $160.25,143.53,133.66,131.66,128.96$, & $135.40,123.09,121.39$ & $72.45,70.98,70.88,70.77,69.28,59.57,50.79$ \\
& $30.09,29.99,26.79,23.42,14.86$ & $128.84,125.31,115.75$ & \\
\hline $\mathbf{3 6 a}$ & $70.35,23.26,11.24$ & $160.25,143.72,133.48,131.66,129.10$, & $136.01,125.49,120.79$ & $72.48,71.00,70.89,70.88,69.46,59.66,50.93$ \\
& & $128.88,123.12,115.77$ & \\
\hline $\mathbf{3 6 b}{ }^{a}$ & $70.40,23.31,11.26$ & $160.29,143.69,133.67,131.73,129.05$, & $135.56,125.37,121.35$ & $72.49,70.99,70.90,70.81,69.35,59.59,50.87$ \\
\hline
\end{tabular}

${ }^{a}$ Collected on a $300 \mathrm{MHz}$ spectrometer. 


\section{${ }^{1} \mathrm{H}$ and ${ }^{13} \mathrm{C}$ NMR dependencies on the counter ion in $15 \mathrm{a}-15 \mathrm{e}$.}

Proton and carbon NMR analysis of the salts in deuterated chloroform showed a strong dependence of the imidazole chemical shifts on the counter ion. The results are summarized in Table S11. The largest differences in chemical shift are observed for the imidazolium proton $\mathrm{H}_{\mathrm{B}}$ with chemical shift ranges between 8.85 and $10.53 \mathrm{ppm}$ for different counter ions. The counter ion effect is also noticeable in the proton shift of the adjacent groups $\mathrm{H}_{\mathrm{A}}$ and $\mathrm{H}_{\mathrm{E}}$. Carbon spectra show much smaller counter ion dependences. Only carbon atom $\mathrm{C}_{2}$ shows a significant difference in this series.

Table S11. Dependence of the ${ }^{1} \mathrm{H}$ and ${ }^{13} \mathrm{C}$ chemical shift on the counter ion.

\begin{tabular}{|c|c|c|c|c|c|c|c|c|c|}
\hline \multirow[t]{2}{*}{ LC } & \multirow[t]{2}{*}{ Anion $\mathrm{X}^{-}$} & \multicolumn{4}{|c|}{${ }_{\mathrm{H}}^{\mathrm{H} \text { chemical shift } \delta / \mathrm{ppm}}$} & \multicolumn{4}{|c|}{${ }^{13} \mathrm{C}$ chemical shift $\delta / \mathrm{ppm}$} \\
\hline & & $\mathrm{H}_{\mathrm{A}}$ & $\mathrm{H}_{\mathrm{B}}$ & $\mathrm{H}_{\mathrm{C}}, \mathrm{H}_{\mathrm{D}}{ }^{a}$ & $\mathrm{H}_{\mathrm{E}}$ & $\mathrm{C}_{1}$ & $\mathrm{C}_{2}$ & $\mathrm{C}_{3}, \mathrm{C}_{4}{ }^{a}$ & $\mathrm{C}_{5}$ \\
\hline $15 a$ & $\mathrm{I}^{-}$ & 7.81 & 10.45 & $7.80,7.76$ & 4.50 & 143.55 & 137.57 & $124.11,121.57$ & 52.64 \\
\hline $15 b$ & $\mathrm{BF}_{4}{ }^{-}$ & 7.66 & 9.24 & $7.66,7.56$ & 4.31 & 143.70 & 135.14 & $123.76,121.78$ & 52.68 \\
\hline $15 \mathrm{c}$ & $\mathrm{PF}_{6}^{-}$ & 7.63 & 8.85 & $7.56,7.47$ & 4.23 & 143.68 & 134.27 & $123.89,122.07$ & 52.64 \\
\hline 15d & $\mathrm{ClO}_{4}^{-}$ & 7.64 & 9.26 & $7.65,7.55$ & 4.31 & 143.55 & 134.93 & $124.01,121.98$ & 52.73 \\
\hline $15 e$ & $\mathrm{H}_{25} \mathrm{C}_{12} \mathrm{SO}_{3}{ }^{-}$ & 7.80 & 10.53 & $7.71,7.50$ & 4.46 & 143.99 & 137.28 & $123.38,121.09$ & 52.97 \\
\hline
\end{tabular}

${ }^{a}$ No attempt was made to distinguish between protons $\mathrm{H}_{\mathrm{C}}$ and $\mathrm{H}_{\mathrm{D}}$ or carbons $\mathrm{C}_{3}$ and $\mathrm{C}_{4}$. 


\section{Instrumental}

${ }^{1} \mathrm{H}$ and ${ }^{13} \mathrm{C}$ NMR spectra were recorded on a Varian VXR-500 (500 MHz) and a Bruker AC-300 (300 MHz) spectrometer. Spectra were recorded in $\mathrm{CDCl}_{3}$ unless mentioned otherwise. Chemical shifts are reported in ppm referenced against TMS, which was added as an internal reference. Most spectra have been recorded on a Varian $500 \mathrm{MHz}$ spectrometer. The spectra recorded on the Bruker $300 \mathrm{MHz}$ (indicated in the tables) have substantially lower resolution. This is best noted in the aliphatic areas of the ${ }^{1} \mathrm{H}$ and ${ }^{13} \mathrm{C}$ NMR spectra where, in some cases, the peaks could not be deconvoluted.

Optical microscopy was carried out using standard glass microscope slides on an Olympus BX60 microscope equipped with a Mettler FP82HT hot stage and digital camera. DSC experiments were performed on a TA Instruments DSC Q100.

Variable temperature X-ray data were collected using an Inel CPS 120 position sensitive detector using an XRG 2000 generator $(\mathrm{Cu} \mathrm{K \alpha})$ and a Minco CT 137 temperature controller. Crushed powder samples were loaded into $1.0 \mathrm{~mm}$ thin walled glass capillary tubes and sealed. XRD data is shown as the intensity as a function of the length of the scattering wave vector $q$, defined as $q=|\mathbf{q}|=4 \pi \sin \theta / n \lambda$, where $\theta$ is the scattering angle, $n$ is an integer and $\lambda$ is the wavelength $\left(\lambda_{\mathrm{Cu}, \alpha \mathrm{K}}=1.54 \AA\right)$. The layer spacing at a particular temperature is determined as the maximum of a fit of a Gaussian distribution to the fundamental reflection in inverse space $q$. Then, the (layer) spacing $d$ was calculated by $d_{001}=2 \pi / q_{\text {FIT }}$, where $q_{\text {FIT }}$ is the peak position of the fitted curve.. Temperature scans were performed as cooling runs. Because of severe hysteresis, transition temperatures observed in XRD may be lower than those recorded by DSC. 


\section{Mesomorphic properties ionic liquid crystals $15-37$}<smiles>[Y]n1cc[n+](-c2ccc(-c3ccc(OCCCC)cc3)cc2)c1</smiles>

$X^{-}=$

(b) $\mathrm{BF}_{4}{ }^{-}$

(c) $\mathrm{PF}_{6}^{-}$

(e) $\mathrm{H}_{25} \mathrm{C}_{12} \mathrm{SO}_{3}{ }^{-}$

$15 \mathrm{R}^{\prime \prime}=n-$ Propyl

$16 \mathrm{R}^{\prime \prime}=n$-Dodecyl

17 R" $=3,7,11$-Trimethyldodecyl

$18 \mathrm{R}^{\prime \prime}=(S)$-Citronellyl

$19 \mathrm{R}^{\prime \prime}=3,6,9-$ Trioxadecyl
Prop

$\mathrm{C}_{12}$

TMD

Citron

$\mathrm{EG}_{3} \mathrm{Me}$

(d) $\mathrm{ClO}_{4}^{-}$

Chart S1: ILC structures 15-19.

Table S12: Yield and mesomorphic properties of ILCs 15-19 (for structures, see Chart S1)

\begin{tabular}{|c|c|c|c|c|c|c|c|c|c|}
\hline \multirow{2}{*}{$\begin{array}{l}\text { Mesogen } \\
15 a\end{array}$} & \multirow{2}{*}{$\begin{array}{l}\mathrm{X}^{-} \\
\mathrm{I}^{-}\end{array}$} & $y / \%$ & $M$ & \multicolumn{5}{|c|}{ Phase behavior: $T /{ }^{\circ} \mathrm{C}$ and $\left(\Delta H / \mathrm{kJ} \mathrm{mol}^{-1}\right)$} & \multirow{2}{*}{$\begin{array}{l}T_{\text {cr-cr }} /{ }^{\circ} \mathrm{C}(\Delta H / \mathrm{kJ} \\
\left.\mathrm{mol}^{-1}\right)\end{array}$} \\
\hline & & 92 & 574.6 & $\mathrm{Cr}$ & $93(38.8)$ & SmA & $220(0.6)$ & $\mathrm{I} / \mathrm{d}$ & \\
\hline $16 \mathbf{a}$ & $\mathrm{I}^{-}$ & 86 & 700.9 & $\mathrm{Cr}$ & 128 & SmA & $>270$ & d & \\
\hline $17 \mathbf{a}$ & $\mathrm{I}^{-}$ & 84 & 742.9 & $\mathrm{CrX}$ & $151(18.9)$ & SmA & $235(3.8)$ & I & \\
\hline $18 \mathbf{a}$ & $\mathrm{I}^{-}$ & 91 & 670.8 & $\mathrm{CrX}$ & $152(18.7)$ & SmA & $222(3.8)$ & I & $30(0.6)^{b}$ \\
\hline 19a & $\mathrm{I}^{-}$ & 70 & 678.7 & $\mathrm{G}_{\mathrm{SmA}}$ & -1 & SmA & $70(1.7)$ & I & $64(22.1)^{c} ;$ br $T_{\mathrm{cl}}$ \\
\hline $15 \mathrm{~b}$ & $\mathrm{BF}_{4}^{-}$ & 97 & 534.5 & $\mathrm{G}_{\mathrm{SmA}}$ & 8 & SmA & $183(0.6)$ & I & $67(15.0)^{c} ; 77(27.0)^{c}$ \\
\hline 16b & $\mathrm{BF}_{4}^{-}$ & 98 & 660.7 & $\mathrm{CrX}$ & $94(13.1)$ & $\mathrm{SmA}$ & $203(3.4)$ & I & \\
\hline $17 \mathrm{~b}$ & $\mathrm{BF}_{4}^{-}$ & 98 & 702.8 & $\mathrm{CrX}$ & $94(14.3)$ & SmA & $203(3.7)$ & I & \\
\hline $18 \mathrm{~b}$ & $\mathrm{BF}_{4}^{-}$ & 96 & 630.7 & $\mathrm{CrX}$ & 94 (14.4) & SmA & $168(2.5)$ & I & \\
\hline 19b & $\mathrm{BF}_{4}^{-}$ & 92 & 638.6 & $\mathrm{CrX}$ & $8(10.4)$ & SmA & $75(0.16)$ & I & $-14.2^{d}$ \\
\hline 15c & $\mathrm{PF}_{6}{ }^{-}$ & 98 & 592.7 & $\mathrm{Cr}$ & $100(31.0)$ & SmA & $140(0.6)$ & $\mathrm{I}$ & \\
\hline 15d & $\mathrm{ClO}_{4}^{-}$ & 88 & 547.2 & $\mathrm{G}_{\mathrm{SmA}}$ & 5 & $\mathrm{SmA}$ & $171(0.5)$ & I & $84(40.6)^{c}$ \\
\hline $15 \mathrm{e}$ & $\mathrm{DS}^{-a}$ & 71 & 697.1 & $\mathrm{Cr}$ & $105(50.6)$ & SmA & $181(3.0)$ & I & \\
\hline
\end{tabular}

${ }^{a} \mathrm{DS}^{-}=\mathrm{H}_{25} \mathrm{C}_{12} \mathrm{SO}_{3}{ }^{-} ;{ }^{b}$ reversible crystal-crystal transition $T /{ }^{\circ} \mathrm{C}\left(\Delta H / \mathrm{kJ} \mathrm{mol}^{-1}\right) ;{ }^{c}$ irreversible crystal-crystal transition (observed at $1^{\text {st }}$ heating only) $T /{ }^{\circ} \mathrm{C}\left(\Delta H / \mathrm{kJ} \mathrm{mol}^{-1}\right) ;{ }^{d}$ glass transition $T_{\mathrm{g}} /{ }^{\circ} \mathrm{C}$. 
<smiles>CCCCCCOc1ccc(C(=O)Oc2ccc(-n3ccnc3)cc2)cc1</smiles><smiles>[X]n1cc[n+](-c2ccc(OC(=O)c3ccc(OCCCC)cc3)cc2)c1</smiles>

$20-22$<smiles>[X]N1C=C[N+](c2ccc(OCCC)cc2)C1</smiles>

$23-25$
$20 \mathrm{R}^{\prime \prime}=n$-Propyl Prop

$21 \mathrm{R}^{\prime \prime}=n$-Dodecyl $\quad \mathrm{C}_{12}$

$22 \mathrm{R}^{\prime \prime}=3,7,11-$ Trimethyldodecyl $\quad T M D$

$23 \mathrm{R}^{\prime \prime}=n$-Propyl Prop

$24 \mathrm{R} "=n$-Dodecyl $\quad \mathrm{C}_{12}$

$25 \mathrm{R}^{\prime \prime}=3,7,11$-Trimethyldodecyl $\quad$ TMD

Chart S2: ILC structures 20-25 and LC precursor 11.

Table S13: Yield and mesomorphic properties of 11 and ILCs 20-22 (structures in Chart S2)

\begin{tabular}{|c|c|c|c|lllll|l|}
\hline Mesogen & $\mathrm{X}^{-}$ & $y / \%$ & $M$ & \multicolumn{5}{|l|}{ Phase behavior: $T /{ }^{\circ} \mathrm{C}$ and $\left(\Delta H / \mathrm{kJ} \mathrm{mol}^{-1}\right)$} & Other transitions \\
\hline $\mathbf{1 1}$ & - & - & 478.7 & $\mathrm{Cr}$ & $102(42.8)$ & $\mathrm{SmA}$ & $130(4.2)$ & $\mathrm{I}$ & \\
\hline 20a & $\mathrm{I}^{-}$ & 89 & 618.6 & $\mathrm{CrY}$ & $140(0.5)$ & $\mathrm{SmA}$ & $214(0.6)$ & $\mathrm{I}$ & $116(11.9)^{a}$ \\
21a & $\mathrm{I}^{-}$ & 92 & 744.9 & $\mathrm{CrY}$ & $160(43.4)$ & $\mathrm{SmA}$ & $233(4.4)$ & $\mathrm{I}$ & $19(14.8)^{a}$ \\
22a & $\mathrm{I}^{-}$ & 90 & 786.9 & $\mathrm{CrZ}$ & $170(38.0)$ & $\mathrm{SmA}$ & $208(3.4)$ & $\mathrm{I}$ & $28(4.3)^{a} ; 47(1.8)^{a}$ \\
\hline 20b & $\mathrm{BF}_{4}^{-}$ & 95 & 578.5 & $\mathrm{G}_{\mathrm{SmA}}$ & 8 & $\mathrm{SmA}$ & $175(0.58)$ & $\mathrm{I}$ & $119(34.7)^{b}$ \\
21b & $\mathrm{BF}_{4}^{-}$ & 94 & 704.8 & $\mathrm{CrY}$ & $130(40.3)$ & $\mathrm{SmA}$ & $201(3.8)$ & $\mathrm{I}$ & $16(14.6)^{a}$ \\
22b & $\mathrm{BF}_{4}^{-}$ & 96 & 746.8 & $\mathrm{CrY}$ & $123(29.9)$ & $\mathrm{SmA}$ & $179(3.1)$ & $\mathrm{I}$ & $26(2.4)^{a} ;-5.8^{c}$ \\
\hline
\end{tabular}

${ }^{a}$ reversible crystal-crystal transition $T /{ }^{\circ} \mathrm{C}\left(\Delta H / \mathrm{kJ} \mathrm{mol}^{-1}\right) ;{ }^{b}$ irreversible crystal-crystal transition (observed at $1^{\text {st }}$ heating only) $T /{ }^{\circ} \mathrm{C}\left(\Delta H / \mathrm{kJ} \mathrm{mol}^{-1}\right) ;^{c}$ glass transition $T_{\mathrm{g}} /{ }^{\circ} \mathrm{C}$.

Table S14: Yield and mesomorphic properties of ILCs 23-25 (for structures, see Chart S2)

\begin{tabular}{|c|c|c|c|lccc|l|l|}
\hline Mesogen & $\mathrm{X}^{-}$ & $y / \%$ & $M$ & \multicolumn{5}{|l|}{ Phase behavior: $T /{ }^{\circ} \mathrm{C}$ and $\left(\Delta H / \mathrm{kJ} \mathrm{mol}^{-1}\right)$} & Other transitions \\
\hline 23a & $\mathrm{I}^{-}$ & 65 & 498.5 & $\mathrm{G}_{\mathrm{SmA}}$ & 1 & $\mathrm{SmA}$ & $57(1.3)$ & $\mathrm{I}$ & $79(30.0)^{b}$ \\
24a & $\mathrm{I}^{-}$ & 78 & 624.8 & $\mathrm{CrY}$ & $85(8.5)$ & $\mathrm{SmA}$ & $184(4.0)$ & $\mathrm{I}$ & $70(29.0)^{a}$ \\
25a & $\mathrm{I}^{-}$ & 75 & 666.8 & $\mathrm{CrX}$ & $83(8.0)$ & $\mathrm{SmA}$ & $153(3.3)$ & $\mathrm{I}$ & \\
\hline 24b & $\mathrm{BF}_{4}^{-}$ & 87 & 584.6 & $\mathrm{CrX}$ & $62(7.5)$ & $\mathrm{SmA}$ & $141(3.0)$ & $\mathrm{I}$ & \\
25b & $\mathrm{BF}_{4}^{-}$ & 90 & 626.7 & $\mathrm{CrX}$ & $69(8.6)$ & $\mathrm{SmA}$ & $126(2.8)$ & $\mathrm{I}$ & $75(69.5)^{b}$ \\
\hline
\end{tabular}

${ }^{a}$ reversible crystal-crystal transition $T /{ }^{\circ} \mathrm{C}\left(\Delta H / \mathrm{kJ} \mathrm{mol}^{-1}\right) ;{ }^{b}$ irreversible crystal-crystal transition (observed at $1^{\text {st }}$ heating only) $T /{ }^{\circ} \mathrm{C}\left(\Delta H / \mathrm{kJ} \mathrm{mol}^{-1}\right)$. 


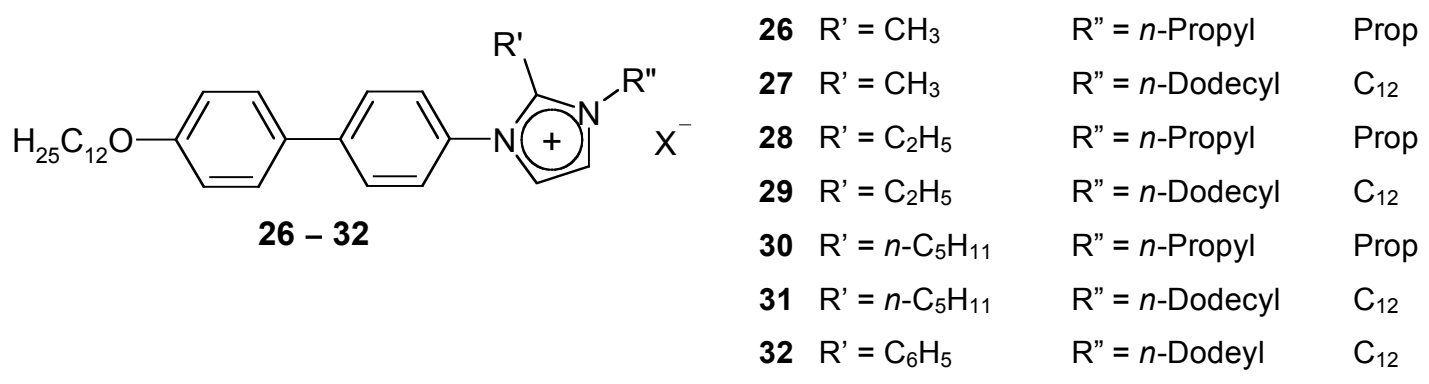

Chart S3: ILC structures 26-32

Table S15: Yield and mesomorphic properties ILCs 26 and 27 (for structures, see Chart S3)

\begin{tabular}{|c|c|c|c|c|c|c|c|c|c|}
\hline Mesogen & $\mathrm{X}^{-}$ & $y / \%$ & $M$ & \multicolumn{5}{|c|}{ Phase behavior: $T /{ }^{\circ} \mathrm{C}$ and $\left(\Delta H / \mathrm{kJ} \mathrm{mol}^{-1}\right)$} & Other transitions \\
\hline $26 \mathbf{a}$ & $\mathrm{I}^{-}$ & 92 & 588.6 & $\operatorname{SmX} ?$ & $46(0.7)$ & $\mathrm{SmA}$ & $206(1.0)$ & I & $11\left(T_{\mathrm{g}}\right)^{a}$ \\
\hline $27 \mathbf{a}$ & $\mathrm{I}^{-}$ & 90 & 714.9 & $\mathrm{CrX}$ & $107(25.3)$ & $\mathrm{SmA}$ & $262(3.6)$ & $\mathrm{I} / \mathrm{d}$ & \\
\hline 26b & $\mathrm{BF}_{4}{ }^{-}$ & 92 & 548.5 & $\operatorname{SmX}$ ? & $41 \quad(0.4)$ & $\mathrm{SmA}$ & $145(0.4)$ & I & $1\left(T_{\mathrm{g}}\right)^{a} ; 64(29.7)^{b}$ \\
\hline $27 b$ & $\mathrm{BF}_{4}^{-}$ & 93 & 674.7 & $\mathrm{CrX}$ & $80(41.8)$ & $\mathrm{SmA}$ & $219(3.2)$ & $\mathrm{I} / \mathrm{d}$ & \\
\hline
\end{tabular}

${ }^{c}$ glass transition $T_{\mathrm{g}} /{ }^{\circ} \mathrm{C} ;{ }^{b}$ irreversible crystal-crystal transition (observed at $1^{\text {st }}$ heating only) $T /{ }^{\circ} \mathrm{C}(\Delta H / \mathrm{kJ}$ $\left.\mathrm{mol}^{-1}\right)$.

Table S16: Yield and mesomorphic properties ILCs $\mathbf{2 8}$ and 29 (for structures, see Chart S3)

\begin{tabular}{|c|c|c|c|lclll|l|}
\hline Mesogen & $\mathrm{X}^{-}$ & $y / \%$ & $M$ & \multicolumn{2}{|l|}{ Phase behavior: $T /{ }^{\circ} \mathrm{C}$} & and $\left(\Delta H / \mathrm{kJ} \mathrm{mol}^{-1}\right)$ & Other transitions \\
\hline 28a & $\mathrm{I}^{-}$ & 87 & 602.6 & $\mathrm{G}_{\mathrm{SmA}}$ & 18 & $\mathrm{SmA}$ & $148(0.3)$ & $\mathrm{I}$ & $108(38.2)^{a}$ \\
29a & $\mathrm{I}^{-}$ & 82 & 728.9 & $\mathrm{Cr}$ & $131(34.7)$ & $\mathrm{SmA}$ & $197(2.4)$ & $\mathrm{I}$ & $-10(\mathrm{broad})^{b}$ \\
\hline 28b & $\mathrm{BF}_{4}^{-}$ & 97 & 562.5 & $\mathrm{G}_{\mathrm{SmA}}$ & -2 & $\mathrm{SmA}$ & $123(0.3)$ & $\mathrm{I}$ & $63(26.8)^{a}$ \\
29b & $\mathrm{BF}_{4}^{-}$ & 97 & 688.7 & $\mathrm{X} ?$ & $61(0.7)$ & $\mathrm{SmA}$ & $149(1.6)$ & $\mathrm{I}$ & $-3\left(T_{\mathrm{g}}\right)^{c}$ \\
\hline
\end{tabular}

${ }^{a}$ irreversible crystal-crystal transition (observed at $1^{\text {st }}$ heating only) $T /{ }^{\circ} \mathrm{C}\left(\Delta H / \mathrm{kJ} \mathrm{mol}^{-1}\right) ;{ }^{b}$ reversible crystalcrystal transition $T /{ }^{\circ} \mathrm{C}\left(\Delta H / \mathrm{kJ} \mathrm{mol}^{-1}\right) ;{ }^{c}$ glass transition $T_{\mathrm{g}} /{ }^{\circ} \mathrm{C}$.

Table S17: Yield and properties of $\mathbf{3 0}$ and $\mathbf{3 1}$ (for structures, see Chart S3)

\begin{tabular}{|c|c|c|c|c|c|c|c|}
\hline Mesogen & $\mathrm{X}^{-}$ & $y / \%$ & $M$ & \multicolumn{3}{|c|}{ Phase behavior: $T /{ }^{\circ} \mathrm{C}$ and $\left(\Delta H / \mathrm{kJ} \mathrm{mol}^{-1}\right)$} & Other transitions \\
\hline 30a & $\mathrm{I}^{-}$ & 83 & 644.8 & $\mathrm{Cr}$ & $90(27.5)$ & I & \\
\hline $31 \mathbf{a}$ & $\mathrm{I}^{-}$ & 76 & 771.0 & $\mathrm{Cr}$ & $123(25.6)$ & I & $57(6.9)^{a} ; 101(13.0)^{a}$ \\
\hline 30b & $\mathrm{BF}_{4}$ & 98 & 604.6 & $\mathrm{Cr}$ & $76(32.8)$ & $\mathrm{I}$ & \\
\hline $31 b$ & $\mathrm{BF}_{4}^{-}$ & 93 & 730.9 & $\mathrm{Cr}$ & $85(25.2)$ & I & \\
\hline
\end{tabular}

${ }^{a}$ reversible crystal-crystal transition $T /{ }^{\circ} \mathrm{C}\left(\Delta H / \mathrm{kJ} \mathrm{mol}^{-1}\right)$. 
Table S18: Yield and properties of 32 (for structures, see Chart S3)

\begin{tabular}{|c|c|c|c|c|c|c|}
\hline Mesogen & $\mathrm{X}^{-}$ & $y / \%$ & $M$ & Phase behavior: $T /$ & & $T_{\text {cr-cr }} /{ }^{\circ} \mathrm{C}\left(\Delta H / \mathrm{kJ} \mathrm{mol}^{-1}\right)$ \\
\hline $32 \mathrm{a}$ & $\mathrm{I}^{-}$ & 67 & 777.0 & $87(39.0)$ & I & \\
\hline 32b & $\mathrm{BF}_{4}{ }^{-}$ & 72 & 736.8 & $82(27.4)$ & I & \\
\hline
\end{tabular}

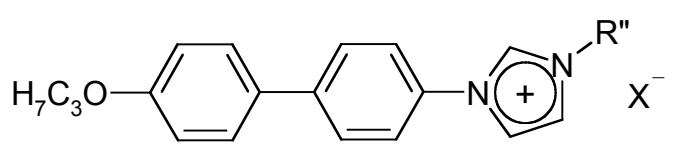

$33-36$

$\begin{array}{lll}33 & \mathrm{R}=n \text {-Propyl } & \text { Prop } \\ 34 & \mathrm{R}=n \text {-Dodecyl } & \mathrm{C}_{12} \\ 35 & \mathrm{R}=3,7,11-\text { Trimethldodecyl } & \mathrm{TMD} \\ 36 & \mathrm{R}=3,6,9 \text {-Trioxadecyl } & \mathrm{EG}_{3} \mathrm{Me}\end{array}$

Chart S4: ILC structures 33-36.

Table S19: Yield and properties of $\mathbf{3 2}$ and $\mathbf{3 3}$ (for structures, see Chart S3)

\begin{tabular}{|c|c|c|c|c|c|c|c|c|c|}
\hline Mesogen & $\mathrm{X}^{-}$ & $y / \%$ & $M$ & \multicolumn{5}{|c|}{ Phase behavior: $T /{ }^{\circ} \mathrm{C}$ and $\left(\Delta H / \mathrm{kJ} \mathrm{mol}^{-1}\right)$} & $T_{\text {cr-cr }} /{ }^{\circ} \mathrm{C}\left(\Delta H / \mathrm{kJ} \mathrm{mol}^{-1}\right)$ \\
\hline 33a & $\mathrm{I}^{-}$ & 80 & 448.4 & $\mathrm{G}_{\text {Iso }}$ & 36 & - & & I & $147(34.0)^{a}$ \\
\hline $34 \mathbf{a}$ & $\mathrm{I}^{-}$ & 90 & 574.6 & $\mathrm{CrX}$ & $120(14.3)$ & SmA & $199(4.2)$ & I & \\
\hline $35 \mathbf{a}$ & $\mathrm{I}^{-}$ & 92 & 616.7 & $\mathrm{CrX}$ & $143(15.8)$ & SmA & $189(4.2)$ & I & $12\left(T_{\mathrm{g}}\right)^{b}$ \\
\hline $36 \mathbf{a}$ & $\mathrm{I}^{-}$ & 59 & 552.5 & $\mathrm{G}_{\text {Iso }}$ & -24 & & & I & $147(8.3)^{a}$ \\
\hline 34b & $\mathrm{BF}_{4}{ }^{-}$ & 96 & 534.5 & $\mathrm{G}_{\mathrm{SmA}}$ & -8 & $\mathrm{SmA}$ & $121(2.1)$ & I & \\
\hline $35 b$ & $\mathrm{BF}_{4}^{-}$ & 93 & 576.6 & $\mathrm{CrX}$ & $68 \quad(4.4)$ & $\mathrm{SmA}$ & $132(3.3)$ & I & $74(10.3)^{c}$ \\
\hline $36 b$ & $\mathrm{BF}_{4}^{-}$ & 67 & 512.4 & $\mathrm{G}_{\text {Iso }}$ & -30 & & & I & \\
\hline $33 e$ & $\mathrm{DS}^{-}$ & 71 & 570.9 & $\mathrm{Cr}$ & $104(54.4)$ & & & I & \\
\hline $34 \mathrm{e}$ & $\mathrm{DS}^{-}$ & 62 & 697.1 & $\mathrm{Cr}$ & $135(37.4)$ & & & I & \\
\hline
\end{tabular}

${ }^{a}$ irreversible crystal-crystal transition (observed at $1^{\text {st }}$ heating only) $T /{ }^{\circ} \mathrm{C}\left(\Delta H / \mathrm{kJ} \mathrm{mol}^{-1}\right) ;{ }^{b}$ glass transition $T_{\mathrm{g}} /$ ${ }^{\circ} \mathrm{C} ;{ }^{c}$ reversible crystal-crystal transition $T /{ }^{\circ} \mathrm{C}\left(\Delta H / \mathrm{kJ} \mathrm{mol}^{-1}\right)$. 


\section{X-ray diffraction results of selected mesogens}

Table S20: Phase behavior and XRD results: Effect of the alkyl substituent

\begin{tabular}{|c|c|c|c|c|c|c|c|c|c|c|}
\hline \multirow[b]{2}{*}{ Mesogen } & \multirow{2}{*}{$\mathrm{x}^{-}$} & \multirow{2}{*}{$\begin{array}{c}T_{\text {Iso } /} \\
\mathrm{K}\end{array}$} & \multirow[b]{2}{*}{$L_{\text {calc }} / \AA$} & \multicolumn{3}{|c|}{ @ $T=0.95 \cdot T_{\text {Iso }}$} & \multicolumn{3}{|c|}{ @ $T=0.90 \cdot T_{\text {Iso }}$} & \multirow{2}{*}{$\frac{L_{0.90} / L_{c}}{L_{0.95} / L_{c}}$} \\
\hline & & & & $T / \mathrm{K}$ & $l_{\text {XRD }} /$ & $L / L_{c}$ & $T / \mathrm{K}$ & $\underset{\mathrm{XRD}}{l_{\mathrm{X}}} /$ & $L / L_{c}$ & \\
\hline $15 b$ & Prop & 456 & 30.5 & 433 & 44.5 & 0.73 & 410 & 46.9 & 0.77 & 0.039 \\
\hline $16 \mathrm{~b}$ & $\mathrm{C}_{12}$ & 476 & 41.5 & 452 & 31.7 & 0.76 & 428 & 32.3 & 0.78 & 0.014 \\
\hline $17 \mathrm{~b}$ & TMD & 476 & 41.2 & 452 & 30.9 & 0.75 & 428 & 31.4 & 0.76 & 0.012 \\
\hline $18 \mathrm{~b}$ & Citron & 441 & 36.7 & 419 & 29.5 & 0.80 & 397 & 29.8 & 0.81 & 0.007 \\
\hline $19 \mathrm{~b}$ & $\mathrm{EG}_{3} \mathrm{Me}$ & 348 & 38.0 & 331 & 48.4 & 0.64 & 313 & 53.3 & 0.70 & 0.065 \\
\hline \multicolumn{2}{|c|}{$\mathbf{1 9 b}+0.5$ eq. $\mathrm{LiBF}_{4}$} & 428 & 38.0 & 407 & 45.5 & 0.60 & 385 & 47.2 & 0.62 & 0.022 \\
\hline \multicolumn{2}{|c|}{$\mathbf{1 9 b}+1$ eq. $\mathrm{LiBF}_{4}$} & 468 & 38.0 & 445 & 45.2 & 0.59 & 421 & 46.8 & 0.62 & 0.021 \\
\hline
\end{tabular}

Table S20: Phase behavior and XRD results: Effect of the counter ion

\begin{tabular}{|c|c|c|c|c|c|c|c|c|c|c|}
\hline \multirow{2}{*}{ Mesogen } & \multirow{2}{*}{$\mathrm{X}^{-}$} & \multirow{2}{*}{$\begin{array}{c}T_{\text {Iso }} / \\
\mathrm{K}\end{array}$} & $L_{\text {calc }} / \AA$ & \multicolumn{3}{|c|}{$@ T=0.95 \cdot T_{\text {Iso }}$} & \multicolumn{3}{|c|}{$@ T=0.90 \cdot T_{\text {Iso }}$} & \multirow{2}{*}{$\frac{L_{0.90} / L_{c}}{n}$} \\
\cline { 5 - 9 } & & & & $T / \mathrm{K}$ & $\begin{array}{c}l_{\text {XRD }} \\
/ \AA\end{array}$ & $L / L_{c}$ & $T / \mathrm{K}$ & $\begin{array}{c}l_{\text {XRD }} / \\
\AA\end{array}$ & $L / L_{c}$ & $L_{0.95} / L_{c}$ \\
\hline $\mathbf{1 5 a}$ & $\mathrm{I}^{-}$ & 493 & 30.5 & 468 & 41 & 0.67 & 444 & 44.7 & 0.73 & 0.061 \\
\hline $\mathbf{1 5 b}$ & $\mathrm{BF}_{4}^{-}$ & 456 & 30.5 & 433 & 44.5 & 0.73 & 410 & 46.9 & 0.77 & 0.039 \\
\hline $\mathbf{1 5}$ & $\mathrm{PF}_{6}^{-}$ & 413 & 30.5 & 392 & 45.5 & 0.75 & 372 & 47.5 & 0.78 & 0.033 \\
\hline $\mathbf{1 5 d}$ & $\mathrm{ClO}_{4}^{-}$ & 444 & 30.5 & 422 & 43.5 & 0.71 & 400 & 46.3 & 0.76 & 0.046 \\
\hline $\mathbf{1 5 e}$ & $\mathrm{DS}^{-}$ & 454 & 44.2 & 431 & 32 & 0.72 & 409 & 33.0 & 0.75 & 0.023 \\
\hline
\end{tabular}

Table S21: Phase behavior and XRD results: Effect of the core size $\left(\mathrm{R}=\mathrm{C}_{12} \mathrm{H}_{25}\right)$

\begin{tabular}{|c|c|c|c|c|c|c|c|c|c|c|}
\hline \multirow{2}{*}{ Mesogen } & \multirow{2}{*}{ core } & \multirow{2}{*}{$\begin{array}{c}T_{\text {Iso }} / \\
\mathrm{K}\end{array}$} & \multirow{2}{*}{$\begin{array}{c}L_{\text {calc }} / \\
\AA\end{array}$} & \multicolumn{3}{|c|}{ (a) $T=0.95 \cdot T_{\text {Iso }}$} & \multicolumn{3}{|c|}{ @ $T=0.90 \cdot T_{\text {Iso }}$} & \multirow{2}{*}{$\frac{L_{0.90} / L_{c}}{L_{0.95} / L_{c}}$} \\
\hline & & & & $T / \mathrm{K}$ & $l_{\text {XRD }} /$ & $L / L_{c}$ & $T / \mathrm{K}$ & $\begin{array}{c}l_{\mathrm{XRD}} / \\
\AA\end{array}$ & $L / L_{c}$ & \\
\hline $16 \mathrm{~b}$ & $\mathrm{PhPhIm}$ & 476 & 41.5 & 452 & 31.7 & 0.76 & 428 & 32.3 & 0.78 & 0.014 \\
\hline $21 b$ & $\mathrm{PhCO}_{2} \mathrm{PhIm}$ & 474 & 44 & 450 & 32.9 & 0.75 & 427 & 33.7 & 0.77 & 0.019 \\
\hline $24 b$ & PhIm & 457 & 37.5 & 434 & 26.4 & 0.70 & 411 & 27.0 & 0.72 & 0.015 \\
\hline $27 \mathrm{~b}$ & PhPhMeIm & 492 & 41.5 & 467 & 30.5 & 0.73 & 443 & 30.7 & 0.74 & 0.005 \\
\hline $29 b$ & PhPhEtIm & 422 & 41.5 & 401 & 30.9 & 0.74 & 380 & 31.2 & 0.75 & 0.008 \\
\hline
\end{tabular}




\section{Molecular modeling}

All structures were first subjected to structural minimization by molecular mechanics, ${ }^{23 a}$ which yielded extended all-trans conformations (Figure S1a). When the dodecylsulphonate group was used as anion (Figure S1b) we also obtained fully extended structures and reliable values for the molecular length. The structures of three selected mesogens did not change significantly after subjecting them to more advanced semi-empirical or ab initio methods (AM1, PM3 and Hartree-Fock STO, 6-31G* force fields). ${ }^{23 b}$ Since the main purpose of this study was to define the molecular dimensions of the extended geometry of the mesogens (to be compared with the XRD results), further theoretical analysis of the structures was not pursued.

Interesting behavior was observed for the glycol material 19b. Calculations by multiple methods (all single molecule in the gas phase) showed that the oligoethyleneglycol tail was not extended, but rather folded over in order to interact with the imidazolium cation with the oxygen atoms pointing towards the charged ring (Figure S1c). This tail-imidazolium interaction is likely the cause for the unusual mesomorphic properties that this particular material displays. Molecular dynamics studies of two mesogenic groups also give strongly interdigitated dimers wherein, the glycol tail of one mesogen interacts with the imidazolium group of the other and vice versa. Such structures could be considered more favorable since the glycol tails are more extended and are the structures are also consistent with the large degree of interdigitation observed in x-ray diffraction experiments. The "dimer" shown in Figure S1d is energy minimized. However, to obtain a more reliable picture, one would need to minimize a sufficiently large ensemble of these molecules, which lies far beyond our own capabilities. 
(a)

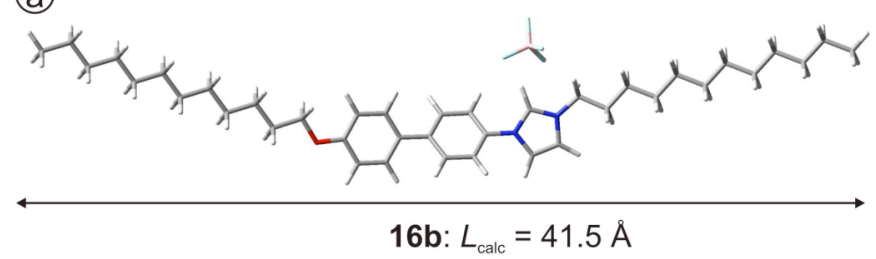

(b)

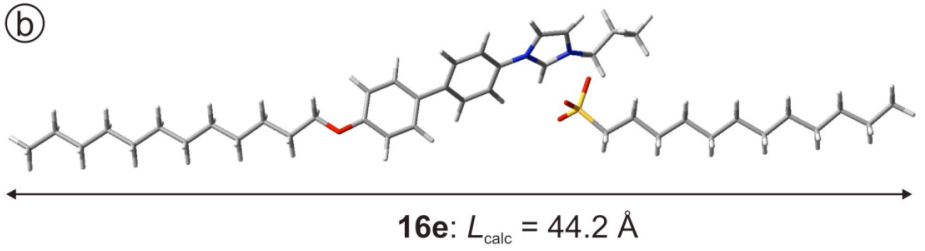

(C)
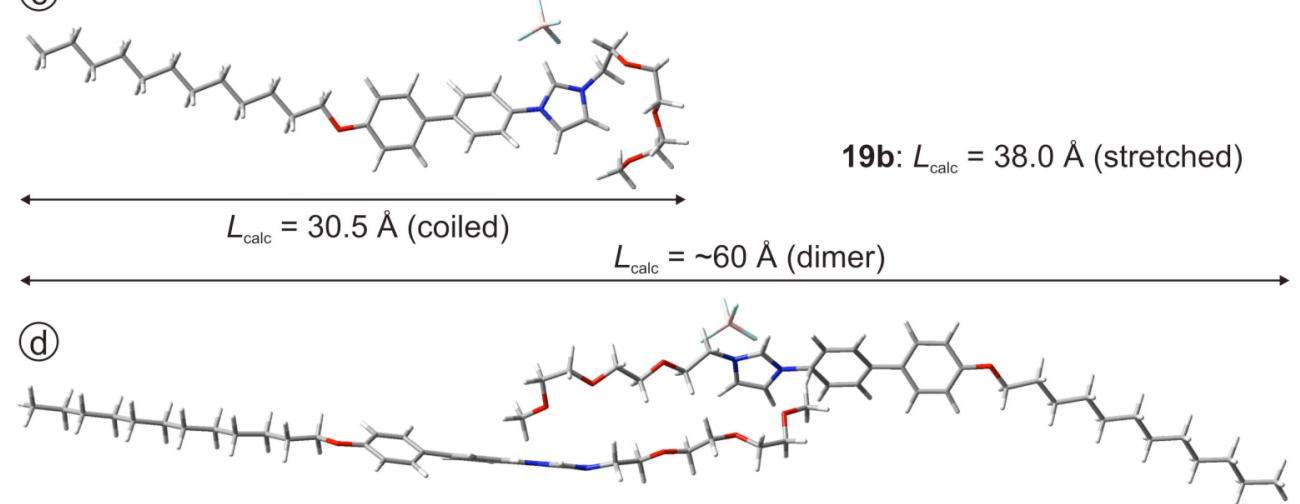

Figure S1. Minimized structures of (a) 16b; (b) 15e; and (c) 15d. The dimeric structure in (d) represents the strongly interdigitated bilayered structure with glycol-imidazolium interactions, discussed in the text. 


\section{References}

(1) Kiryanov, A. A.; Sampson, P.; Seed, A. J. J. Mat. Chem. 2000, 11, 3068-3077.

(2) Zang, Z.-Q.; Zhang, D.; Wan, X.-H.; Zhou, Q.-F. Mol. Cryst. Liq. Cryst. 2000, 339, 145-158.

(3) Tang, Y. G.; Gong, Z.; Wen, J. X. Mol. Cryst. Liq. Cryst. 2000, 348, 153-166.

(4) Berdaque, P.; Perez, F.; Courtieu, J.; Bayle, J. P. Bull. Soc. Chim. Fr. 1993, 130, $475-$ 480.

(5) Bennett, C. J.; Caldwell, S. T.; McPhail, D. B.; Morrice, P. C.; Duthie, G. G.; Hartley, R. C. Bioorg. Med. Chem. 2004, 12, 2079-2098.

(6) Berkowitz, D.B.; Bose, M.; Asher, N.G. Org. Lett. 2001, 3, 13, 2009-2012.

(7) Jullien, L.; Canceill, J.; Lacombe, L.; Lehn, J.M. J. Chem. Soc. Perkins Trans. 2 1995, $417-426$

(8) Modeling software: (a) CambridgeSoft, Chem3D Pro version 5.0, MM2 minimization. (b) Gaussian 03W Version 6.0. 